\title{
Industries and the bank lending effects of bank credit demand and monetary policy in Germany
}

Citation for published version (APA):

Raabe, K., Arnold, I. J. M., \& Kool, C. J. M. (2006). Industries and the bank lending effects of bank credit demand and monetary policy in Germany. METEOR, Maastricht University School of Business and Economics. METEOR Research Memorandum No. 006 https://doi.org/10.26481/umamet.2006006

Document status and date:

Published: 01/01/2006

DOI:

10.26481/umamet.2006006

Document Version:

Publisher's PDF, also known as Version of record

\section{Please check the document version of this publication:}

- A submitted manuscript is the version of the article upon submission and before peer-review. There can be important differences between the submitted version and the official published version of record.

People interested in the research are advised to contact the author for the final version of the publication, or visit the DOI to the publisher's website.

- The final author version and the galley proof are versions of the publication after peer review.

- The final published version features the final layout of the paper including the volume, issue and page numbers.

Link to publication

\footnotetext{
General rights rights.

- You may freely distribute the URL identifying the publication in the public portal. please follow below link for the End User Agreement:

www.umlib.nl/taverne-license

Take down policy

If you believe that this document breaches copyright please contact us at:

repository@maastrichtuniversity.nl

providing details and we will investigate your claim.
}

Copyright and moral rights for the publications made accessible in the public portal are retained by the authors and/or other copyright owners and it is a condition of accessing publications that users recognise and abide by the legal requirements associated with these

- Users may download and print one copy of any publication from the public portal for the purpose of private study or research.

- You may not further distribute the material or use it for any profit-making activity or commercial gain

If the publication is distributed under the terms of Article $25 \mathrm{fa}$ of the Dutch Copyright Act, indicated by the "Taverne" license above, 


\title{
Industries and the Bank Lending Effects of Bank Credit Demand and Monetary Policy in Germany
}

\author{
by \\ Katharina Raabe*, Ivo J.M. Arnold ${ }^{\dagger}$, and Clemens J.M. Kool ${ }^{\ddagger}$
}

February 07, 2006

\begin{abstract}
This paper presents evidence on the industry effects of bank lending in Germany and asks whether bank lending to single industries depends on industry-specific bank credit demand or on monetary policy as determinant of bank credit supply. To this end, we estimate individual bank lending functions for 17 manufacturing and non-manufacturing industries and five banking groups using quarterly bank balance sheet and bank lending data for the period 1992:1-2002:4. The evidence from dynamic panel data models illustrates that industry bank lending responds more to changes in industry-specific bank credit demand than to changes in monetary policy. We report evidence in favor of a credit channel through bank lending, but find the bank lending effects of monetary policy to be very sensitive to the choice of industry. The empirical results, hence, lend strong support to the existence of industry effects of bank lending. In view of this finding, we conclude that bank lending growth and monetary policy effectiveness crucially depend on the industry composition of bank credit portfolios.
\end{abstract}

Keywords : Monetary policy transmission, credit channel, industry structure, dynamic panel data.

JEL Classification : C23, E52, G21, L16.

*Corresponding author: Universiteit Maastricht (FdEWB), Department of Economics, P.O. Box 616, 6200 MD Maastricht, The Netherlands. Phone: ++31-43-3883691; E-mail: K.Raabe@algec.unimaas.nl.

$\dagger$ Universiteit Nyenrode, The Netherlands.

¥Utrecht School of Economics, Universiteit Utrecht, The Netherlands.

This research was conducted at the Deutsche Bundesbank. We would like to thank the banking supervision department and economic research department of the Deutsche Bundesbank for their hospitality. We are also grateful to the statistics department of the Deutsche Bundesbank for providing the bank level data and to Ingo Steinert for explanations regarding their structural pattern. We also want to thank Andreas Worms, Michael Kötter and Stephanie Stolz for interesting discussions and valuable comments. This paper represents the authors' personal opinions and does not necessarily reflect the views of the Deutsche Bundesbank. 


\section{Contents}

1 Introduction 2

2 The Credit Channel Effects of Monetary Policy in Germany 5

3 Banks and Industries in Germany: An Overview 8

3.1 The Structure of the German Banking Sector . . . . . . . . . . . . . . . . . 8

3.2 The Industry Structure of Bank Loan Portfolios . . . . . . . . . . . . . . . . . 11

3.3 What Explains Differences in Bank Lending? . . . . . . . . . . . . . . . . . 12

3.4 Industry Determinants of Bank Lending . . . . . . . . . . . . . . . . . . . . 14

3.5 Synthesis . . . . . . . . . . . . . . . . . . . . 17

4 Empirical Model $\quad 18$

4.1 Empirical Estimation Framework . . . . . . . . . . . . . . . . . . . 18

4.2 Methodology . . . . . . . . . . . . . . . . . . . . 20

5 Data 21

6 Empirical Results 24

6.1 Analysis of Variance Tests . . . . . . . . . . . . . . . . . . . . . . . . . . . 26

6.2 Evidence from Industry-Specific Bank Lending Functions . . . . . . . . . . . 27

6.2.1 The Bank Lending Effects of Loan Demand and Monetary Policy . . 28

6.2.2 Are there Bank Lending Effects of Monetary Policy? . . . . . . . . . 30

6.2.3 Comparison of the Results with Existing Studies . . . . . . . . . . . 33

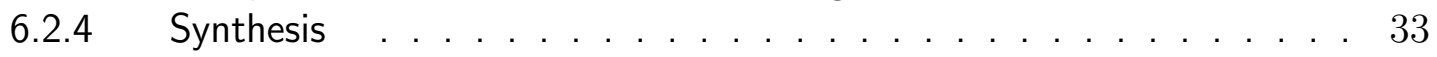

6.3 Robustness Tests . . . . . . . . . . . . . . . . . . . . . . . . . . . . . . . 34

7 Conclusion $\quad 36$ 


\section{Introduction}

Monetary policy changes are propagated through a multitude of transmission channels such as, for example, the credit and interest rate channel. Both types of transmission channels predict bank lending to change in response to monetary policy actions. While the direction of the change is the same in the credit and interest rate view, the underlying reasons differ. The credit channel view explains monetary policy induced movements in bank lending with changes in bank loan supply, whereas the interest rate channel stresses changes in bank loan demand. Apparently, the correlation of monetary policy shocks with loan demand and loan supply and the consequent role of interest rates as joint determinant of credit demand and credit supply precludes the unique identification of the interest rate and credit channel effects of monetary policy.

In order to solve the problem of identifying the loan supply and loan demand effects of monetary policy, empirical studies typically rely on disaggregated macro or micro data. These illustrate the distributional effects of monetary policy by stressing within-group and betweengroup heterogeneity of banks in terms of asset size (e.g., Kashyap and Stein, 1995), liquidity (e.g., Kashyap and Stein, 2000), and capitalization (e.g., Peek and Rosengren, 1995). The identification of loan supply effects builds on the assumption that bank heterogeneity in bank size, liquidity, and capitalization reflects cross-bank differences in the severity of asymmetric information problems and therefore differences in the ability of banks to offset monetary policy induced changes in deposits with other types of finance. When stressing bank-specific characteristics, the identification of credit supply effects is achieved by assuming that the response of bank credit supply to changes in bank credit demand is homogenous across all banks. ${ }^{1}$ Besides, banks are assumed to serve customers which do not differ in terms of bank credit demand and for which bank credit demand is determined by similar factors. These are strong assumptions and their likely violation suggests the persistence of the identification problem.

The identification bias is likely to be particularly strong for Germany for two reasons. The first reason refers to the housebank principle in German banking. German banks belong to banking groups which confine their business to customers which differ in the degree of bank dependence. Commercial banks are the housebank to large corporations, while savings and cooperative banks are the housebanks to small- and medium-sized firms. ${ }^{2}$ In general, small firms are more dependent on banks as source of external finance than large firms. The greater bank dependence results from credit market imperfections which are more pronounced for small than for large firms given that reporting and accounting standards become more stringent with firm size. Credit market imperfections therefore cause the portfolio of savings and cooperative banks to be biased towards bank-dependent firms and that of commercial banks to be biased towards firms with access to non-bank sources of finance (cf. Deutsche Bundesbank, 1998a, 2002a). In view of these relationships, banking groups are likely to differ in the extent to which they (i) face changes in credit demand and (ii) adjust credit supply.

\footnotetext{
${ }^{1}$ For details see Deutsche Bundesbank (2001) and Worms (2003). This is comparable to arguments regarding the firm size effects of monetary policy, where it is assumed that the interest rate sensitivity of credit demand does not depend on firm size.

${ }^{2}$ See Elsas and Krahnen (2004) for evidence on the role of housebanks as source of finance for small and large firms in Germany.
} 
The second reason refers to the existence of pronounced cross-industry differences in credit demand. The Deutsche Bundesbank (1996) attributes these to heterogeneities in the cyclical and structural characteristics of industries. The cyclicality of industry output affects the need for external finance through its effect on the availability of internal funds of finance. Cross-industry differences in bank credit demand reflect dissimilarities in the amplitude and frequency of cyclical fluctuations and in the sensitivity of cash flows to cyclical demand changes. Structural characteristics such as the degree of capital intensity, firm size distribution, or openness to trade explain industry differences in credit demand with differences in the costs of maintaining and expanding production structures and with heterogeneities in the severity of credit market imperfections and the corresponding access to non-bank funds of finance.

Besides possible heterogeneities in bank credit demand and in the response of bank lending to changes in bank credit demand, the identification of the bank credit supply effects of monetary policy is also complicated by the net worth effects of monetary policy. The complication arises because net worth effects cause the volume of bank lending to be determined by bank credit supply side effects and bank credit demand side effects. The supply side effects are at the core of the credit channel theory of monetary policy transmission which links the bank lending decisions of banks to the net worth position of firms. In response to a monetary contraction, the credit channel theory predicts an unambiguous decline in bank credit supply given the deterioration in the balance sheet position of potential borrowers such as firms (cf. Bernanke and Gertler, 1989). ${ }^{3}$ In contrast to bank credit supply, a monetary policy induced decline in net worth has an ambiguous effect on bank credit demand: it may expand or contract. On the one hand, firms may demand more bank credit in response to lower net worth in order to be able to finance fixed and inventory investment and to preserve liquidity. On the other hand, firms may not change or even reduce bank credit demand in the wake of monetary contraction. This reaction requires firms to be swift in adjusting production to the interest rate induced decline in output demand so as to reduce variable costs of production and to avoid the costs associated with undesired inventory accumulation. In addition, bank credit demand may decline when firms delay physical capital investment in anticipation of lower future interest rates.

Overall, the net worth effect of monetary policy causes bank credit supply to contract, while bank credit demand may expand or contract. Unfortunately, we cannot identify the net worth effects on bank credit supply or bank credit demand. However, we do not expect that this shortcoming affects our conclusions regarding the bank supply effects of monetary policy. This is because existing evidence tends to lend no or weak support to the existence of balance sheet effects of monetary policy in Germany. Evidence against the existence of net worth effects is provided by Siegfried (2000), Mojon, Smets, and Vermeulen (2002), and Chatelain et al. (2003), and Arnold and Vrugt (2004). Von Kalckreuth (2001) finds support for the existence of balance sheet effects. ${ }^{4}$ However, the net worth effect of monetary policy is small and attributable to firm creditworthiness rather than to firm size. The relative unimportance of firm size effects is attributed to the strength of housebank relationships which causes the relationship between firm size and financial constraints to be weak.

\footnotetext{
${ }^{3}$ Also see Trautwein (2000) for a literature review on the balance sheet effects of monetary policy and on the relationship between firms' net worth and access to bank credit.

${ }^{4}$ Deutsche Bundesbank (2002b) summarizes and interprets the results.
} 
Existing studies on the bank lending effects of monetary policy build on the assumption that bank credit demand does not differ between debtors in general and industries in particular. They approximate credit demand with macroeconomic aggregates such as real economic output and estimate bank lending functions for the aggregate economy. ${ }^{5}$ Although the macroeconomic data are useful since they are available for long time periods at relatively high frequencies, the underlying models only illustrate the bank lending effects of credit demand changes for the average industry. Differences in credit demand across industries are ignored. In addition, macroeconomic data do not control for possible cross-industry differences in the response of bank lending to monetary policy changes. The effectiveness of monetary policy is, thus, considered to be independent of the industry structure of the loan portfolio of banks. Furthermore, most studies do not consider possible cross-banking group differences in the response of bank lending to changes in bank credit demand or monetary policy. Instead, they typically provide evidence for an aggregate measure of all banks, disregarding cross-banking group effects. ${ }^{6}$

In our view, however, knowledge regarding the industry effects and banking group effects of bank lending is important as the results illustrate whether the effectiveness of monetary policy depends on the institutional setting of the banking system and on the industry composition of bank credit portfolios. Besides, an understanding of banking group effects allows for inferences as to the influence of banking sector consolidation on the likely impact of future monetary policy on bank lending. The identification of industry effects is also important because they influence the allocation of bank credit between industries and, hence, the availability of bank credit to industries. Since German banks are not restricted in the maximum share of credit they can grant to a particular industry ${ }^{7}$, industry effects may cause firms in some industries to be credit constraint even in absence of credit market imperfections.

The present paper is motivated by these considerations. We do not impose the assumption of homogenous bank credit demand and use the industry dimension of bank lending data to identify the bank lending effects of changes in bank credit demand and monetary policy in Germany. In addition, we explicitly allow for cross-banking group differences in bank lending functions to capture structural banking group dissimilarities in terms of customer base which may impede on the homogeneity assumption. To this end, we do not only compile evidence for the aggregate of banking groups, but also for the savings banking group and for the sub-groups of the credit cooperative banking sector. We hypothesize that industries and banking groups determine the response of bank lending to changes in bank credit demand and monetary policy. In particular, we argue that changes in bank lending are industry specific and that the industry composition of a bank's loan portfolio determines the effectiveness of monetary policy through credit channel effects.

We discuss two questions. Firstly, are changes in the industry-specific volume of bank credit explained by bank lending effects of monetary policy or do they reflect changes in industry-

\footnotetext{
${ }^{5}$ See, for example, Deutsche Bundesbank (2002c), De Bondt (1998), Kakes and Sturm (2002), Ehrmann et al. (2003), Worms (2003), Gambacorta and Mistrulli (2004), Hülsewig, Winker, and Worms (2004).

${ }^{6}$ The notable exception is Küppers (2001) and Kakes and Sturm (2002) who distinguish banking groups in empirical studies for Germany.

${ }^{7}$ Limits only prevail with respect to the maximum exposure to a single debtor.
} 
specific bank credit demand? ${ }^{8}$ Secondly, does the sensitivity of bank lending to changes in monetary policy or loan demand differ across industries or across banking groups? The answer to these questions will show that industry bank lending responds much more to changes in industry bank credit demand than to monetary policy changes. Our results lend very strong support to the existence of industry effects of bank lending, whereas banking group effects are comparatively weak. Furthermore, evidence in favor of credit channel effects of monetary policy crucially depends on the choice of industry and banking group. In view of these findings, we conclude that empirical studies which do not control for the industry structure of bank lending provide an incomplete view on the bank lending effects of bank credit demand and monetary policy. The underlying results only reflect the influence of the average industry. However, neglecting banking group effects is unlikely to affect the overall conclusions as to the determinants of bank lending.

The paper is structured as follows. Section 2 reviews the existing evidence on the credit channel effects of monetary policy via bank lending in Germany. Section 3 describes the German banking industry. Within this framework, the discussion stresses the balance sheet structure of the main banking groups and the industry structure of the corresponding loan portfolios. Furthermore, we ask whether bank lending is sensitive to the existence of structural differences between East- and West-Germany. Section 4 discusses the empirical model and the empirical estimation strategy and section 5 presents the data and describes the outlier adjustment method. Section 6 reports the empirical results from dynamic panel estimations and robustness checks. We will ask whether differences in the response of bank lending to changes in industry output, industry prices, and monetary policy are explained by effects associated with banking groups or industries. We conclude in section 7 .

\section{The Credit Channel Effects of Monetary Policy in Germany}

There is a wide range of studies on the bank lending effects of monetary policy in Europe. Because individual firm and bank level data are only available to a small extent, the empirical investigations largely rely on aggregate data. The studies differ in terms of the geographical scope of the analysis, the empirical approach, and the variables used to characterize banks. Furthermore, dissimilarities prevail as to the dimension of the data. Many studies on the credit channel effects of monetary policy ignore the micro structure of the bank credit market and employ highly aggregated loan variables. The corresponding evidence differs in terms of conclusions as to the operation of a credit channel in Europe in general and Germany in particular. As regards the aggregate evidence for Germany, Holtemöller (2003), Hülsewig, Winker, and Worms (2004), Hülsewig, Mayer, and Wollmershäuser (2005) report evidence which is consistent with credit channel effects of bank lending, while Guender and Moersch (1997) report unambiguous evidence against bank lending effects of monetary policy. Garretsen and Swank (1998) find weak support for the transmission of monetary policy changes through bank lending effects in the Netherlands. Banks are found to immediately reduce bond holdings

${ }^{8}$ We cannot control for the response of bank lending to monetary policy induced changes in credit demand. However, to the extent that monetary policy changes affect industry output or industry price only with a lag, changes in the volume of bank loans can still predominantly be attributed to changes in bank credit demand. 
instead of lending in response to a restrictive monetary policy change.

The evidence from studies using aggregate data can be criticized for providing an incomplete view on the bank lending effects of monetary policy. This is because the evidence from aggregate data only captures the net effect of the interest rate reaction of the components of bank lending. Studies which use disaggregated lending data to distinguish bank lending by its components demonstrate the sensitivity of the results to the type of bank loan and to the choice of banking group. Kakes, Sturm and Maier (2001) and Kakes and Sturm (2002) employ disaggregated data on short-, medium-, and long-term lending to households and firms and aggregate lending data by banking groups to test for a credit channel in Germany, respectively. Kakes, Sturm and Maier (2001) report evidence against bank lending effects of monetary policy in Germany. Lending to most loan categories is found to expand rather than to contract in response to a monetary contraction. Kakes and Sturm (2002) report weak evidence supporting the credit channel effects via bank lending in Germany. They find that bank lending effects of monetary policy only exist for the credit cooperative banking group, but not for the commercial or savings banking group. The discrepancy in the result for credit cooperatives and savings banks is interesting since both banking groups operate under comparable institutional setups and serve comparable customers. Küppers (2001) identifies the credit channel effects of monetary policy in Germany for a sample of heterogeneous banks. He reports significant bank size effects of monetary policy. However, inconsistent with the credit channel theory, size effects originate with big banks rather than with savings banks or credit cooperatives.

In an international context, Dale and Haldane (1995) use data on corporate and household lending to assess the bank lending effects of monetary policy for the United Kingdom and report evidence in favor of a credit channel through household bank lending. Barran, Coudert, and Mojon (1997) distinguish corporate, household, and housing real estate lending in Germany and France. Regardless of the borrower type, the evidence is inconsistent with a bank lending channel of monetary policy transmission. Finally, De Haan (2003) investigates the credit channel effects of monetary policy for the Netherlands and distinguishes between short- and long-term loans with and without state guarantees and bank credit to households and firms with and without state guarantees. The corresponding results indicate that bank lending effects of monetary policy only arise for unsecured bank credit in the Netherlands and that bank lending effects are weaker for households than for firms and weaker for short- than for long-term lending.

While studies using disaggregated data allow for more detail on the determinants of bank lending, they still provide an incomplete view since they identify the bank lending effects of monetary policy by means of separate samples. For example, Kakes and Sturm (2002) capture differences in bank size by estimating models for different banking groups which differ in terms of business volume. In contrast to macro-studies, micro-studies exploit heterogeneities within samples to identify the bank credit demand and the bank credit supply effects of monetary policy. The remainder of this section reviews the micro-studies on European countries. Given the focus of the present project, we only discuss studies which contain Germany. ${ }^{9}$ Microstudies for European countries including Germany are reported by De Bondt (1998), Favero,

\footnotetext{
${ }^{9}$ See Angeloni, Kashyp, and Mojon (2003) for a compilation of micro studies which document the credit channel effects of monetary policy in European countries.
} 
Giavazzi, and Flabbi (1999), Altunbaș, Fazylov, and Molyneux (2002), Ehrmann et al. (2003), and Worms (2003). Using data from BankScope, De Bondt (1998) reports panel econometric evidence in support of a bank lending effect of monetary policy for Germany. The bank lending effect is strong in comparison to other European countries and larger for small and less liquid banks. Even though Favero, Giavazzi, and Flabbi (1999) use the same database, the cross-section analysis does not yield evidence of a bank lending effect in Germany. In fact, small banks are found to increase credit supply in response to monetary policy shocks. Also using BankScope data, Altunbaș, Fazylov, and Molyneux (2002) employ a panel estimation framework to provide evidence on the interest rate sensitivity of bank lending in European countries. In line with Favero, Giavazzi, and Flabbi (1999), the results do not point to the operation of a credit channel in Germany.

Ehrmann et al. (2003) question the usefulness of the BankScope database given its well-known large sample bias. They test for the existence of a bank lending effect of monetary policy by using micro data compiled by national central banks. Ehrmann et al. (2003) empirically account for the identification problem of loan demand and loan supply effects by estimating dynamic panel models using bank-specific bank size, liquidity, and capitalization as loan supply proxy variables and macroeconomic measures of economic activity as loan demand variables. The evidence points to the transmission of monetary policy shocks through bank lending. However, cross-bank differences in the reaction of bank lending to monetary policy changes are only attributable to differences in liquidity and not to dissimilarities in asset size and capitalization. As regards loan demand factors, bank lending is found to respond to inflation, but not to output growth.

Worms (2003) presents a study closely related in terms of structure to that of Ehrmann et al. (2003). In line with the earlier study, Worms (2003) uses bank liquidity and bank capitalization next to bank size to test for the operation of a credit channel in Germany. Using a dynamic panel estimation methodology, the evidence largely confirms the results by Ehrmann et al. (2003). Bank lending is found to be more sensitive to changes in monetary policy, the less liquid and capitalized a bank is. Bank size per se only captures cross-bank differences in the bank lending effects of monetary policy when the analysis controls for short-term interbank deposits. Interestingly, the results strengthen if the smallest banks are excluded from the analysis. Worms (2003) attributes this result to the pronounced dependence of small banks on interbank liquidity. Very small banks are argued to hold more short-term interbank deposits to avoid discontinuous and accelerated shifts in their loan portfolio in general and in their lending to private debtors in particular. In that respect, short-term interbank deposits are seen as means to maintain close housebank relationships with bank customers especially in presence of adverse monetary policy shocks.

To summarize, existing studies report ambiguous results regarding the bank lending effects of monetary policy. The ambiguity prevails for micro as well as for macro analyses. Furthermore, existing empirical studies differ in the cross-sectional dimensions of the estimations. Some studies only exploit a single data dimension and divide the banking sample by either bank size, bank liquidity, or bank capitalization. Other studies also split the sample along a second dimension, using the maturity of bank credit, the banking group, or the group of debtors as additional model criterion. Among the existing studies, only Worms (2003) controls for a possible industry bias in bank lending. However, he models the interdependence between 
loan supply and industry indirectly by including a weighted average of real sector output in the panel estimation. The resulting estimates do not allow for inferences as to the industry-specific effects of bank lending.

\section{$3 \quad$ Banks and Industries in Germany: An Overview}

In order to provide the framework for the subsequent discussion, this section describes the German banking system. ${ }^{10}$ We are specifically interested in the balance sheet structure of the main banking groups and in the industry structure of the credit portfolio. The distribution of bank credit to industries and the underlying maturity structure of loans is of particular interest. The data are obtained from the monthly bank balance sheet statistics and the quarterly borrower statistics of the Deutsche Bundesbank. Section 5 describes the data in detail.

\subsection{The Structure of the German Banking Sector}

The financing system in Germany is a bank-based system, with banks being the most important source of external finance. The banking system can be divided into two main categories: universal banks and specialized banks. At the end of 2003, the German banking sector consisted of 2,466 banks of which 2,255 were universal and 211 were special. The German banking system is, hence, a universal banking system. Given this property, the present analysis disregards specialized banks and focuses on the three main universal banking groups, i.e., the savings, cooperative, and commercial banking sector.

Each of the main banking groups can be divided into two tiers. The first tier consists of few large head institutions which are the Land banks, cooperative central banks, and the big banks for the savings, credit cooperative, and commercial banking sector, respectively. The second tier is composed of many primary institutions: local savings banks in the savings banking sector, credit cooperatives in the cooperative banking sector, and regional and private banks in the commercial banking sector. Commercial banks and the head institutions of the savings and credit cooperative sector operate product portfolios which differ from those of the primary savings and credit cooperative banks. The head institutions of the savings and credit cooperative banking sector are the central bank to the corresponding local banks and offer universal banking services to larger foreign and domestic banks and non-bank customers (cf. Hackethal, 2004). Particular to the head institutions of the savings banking group is their role in providing services to the government of the state in which they are located. Considering commercial banks, they structure their product portfolio around investment and wholesale banking activities, predominantly serving large rather than small- and medium-sized clients.

Table1 reports summary statistics for the head and primary institutions regarding the distribution of total assets, bank capitalization, liquidity, short-term interbank claims, and non-bank

\footnotetext{
${ }^{10}$ See Hackethal (2004) for an extensive discussion of the properties of the German banking sector.
} 
lending. ${ }^{11}$ As is evident for the sample period 1992:1-2002:4, the structural differences between head and primary institutions are reflected in the descriptive statistics of balance sheet variables. Primary institutions are on average better capitalized than their respective head institutions even though they are smaller. Besides, local savings banks and regional and private commercial banks tend to be more liquid than Land banks and big banks, while the primary institutions of the cooperative banking sector are on average less liquid than their central institutions. Regardless of the banking group, a comparatively large share of liquidity is accounted for by short-term interbank claims. With the exception of regional and private commercial banks, primary institutions hold a larger share of interbank claims than their respective head institutions.

-Insert Table 1 here-

Considering the distribution of lending to non-banks ${ }^{12}$, the primary institutions in each banking sector lend on average more to non-banks than the respective head institutions. The difference is particularly pronounced for the credit cooperative sector: lending by central institutes accounts on average for 17 percent of total assets, while the corresponding number for credit cooperatives is 60 percent. The central institutions' low involvement in non-bank lending is attributable to their main role as central bank to primary credit cooperatives. In this function they act as clearing institutions for interbank transfers between credit cooperatives and assist primary credit cooperatives in accessing financial markets and in serving their customers. ${ }^{13}$

As regards the share of industry bank credit to non-bank credit, primary and head institutions of the commercial or savings banking group do not differ in the degree of industry lending. A comparatively large share of aggregate non-bank lending is allocated towards industries (i.e., businesses and self-employed), exceeding 50 percent and 40 percent of total non-bank lending for the commercial and savings banking group, respectively. Pronounced differences again prevail between the primary and head institutions of the credit cooperative sector: industry lending by central credit institutes and primary credit cooperatives accounts on average for approximately two-third and four-ninth of total non-bank lending, respectively. Considering the share of short-term lending to total lending, we find considerable differences between head and primary institutions for all banking groups. Except for the credit cooperative sector, head institutions on average provide less short-term finance than primary banks.

The entries in Table 1 also demonstrate that there are not only differences in the balance sheet structure within each banking group, but also between banking groups. These differences are expected to affect the conclusions regarding the bank lending effects of monetary policy for

\footnotetext{
${ }^{11}$ As regards local savings banks, the descriptive statistics refer to public savings banks only. Private savings banks are excluded throughout this paper since they operate under a different institutional setup. The existence of significant differences in the balance sheet structure of public and private savings banks is confirmed by the test statistics of one-way analysis of variance (ANOVA) for almost all sampled balance sheet items. The ANOVA test statistics are available on request.

${ }^{12}$ Non-bank lending involves bank credit supply to domestic businesses, private households, government, and foreign non-banks.

${ }^{13}$ Also see Hackethal (2004).
} 
individual banking groups. For example, banks belonging to banking groups with a relatively large amount of liquid assets (group j) might be better able to insulate their lending activities from monetary policy changes than banks in banking groups with only few liquid assets (group I). If this holds, cross-bank differences in liquidity might be a less important source of bank lending effects of monetary policy in group $\mathrm{j}$ than in group $\mathrm{l}$. This, in turn, suggests that banking group differences in liquidity may affect conclusions regarding the strength of the bank lending effects of monetary policy.

To conserve on space, we confine the comparison to the primary institutions of the banking groups which constitute the focal point of the empirical analysis. As is evident from Table 1 , the largest and most liquid banks operate in the savings banking sector, while the smallest and least liquid banks belong to the group of credit cooperatives. The regional and private banks in the commercial banking sector report the largest share of bank capital, exceeding that of savings and cooperative banks by more than 90 and 60 percent, respectively. The descriptive analysis also shows that each banking group reports a high share of non-bank lending to total assets. Whereas the primary institutions of the credit cooperative and savings banking sector report on average comparable shares of non-bank lending to total assets, the corresponding share tends to be lower for the commercial banking group. This reflect the greater involvement of commercial banks in lending to banks. ${ }^{14}$

However, when looking at the share of total industry lending to non-bank lending, the primary institutions of the commercial banking sector lend on average more to industries than savings banks and credit cooperatives. The descriptive evidence suggests that the difference in the average share of total industry lending reflects considerable differences in the role of banking groups as source of short-term finance to industries. Regional and private commercial banks tend to be more heavily engaged in short-term finance than credit cooperatives or savings banks. In fact, short-term lending to industry $\mathrm{i}$ as share of total industry lending is approximately twice as large for commercial banks than for credit cooperatives and savings banks. The apparent weakness of savings banks and credit cooperatives in short-term finance is attributable to their practice of confining business to local areas. Superior knowledge of local market conditions facilitates assessments regarding the long-term creditworthiness of debtors which yields a comparative advantage in long-term lending.

In order to ascertain the statistical significance of cross-banking group differences in the balance sheet structure, we analyze the variance properties of the bank characteristics by means of a one-way analysis of variance. Table 2 reports the ANOVA test statistics for asset size, liquidity, capitalization, short-term interbank claims, and the volume of bank credit. Panel A contains the results for the three main banking groups, i.e., commercial, savings, and credit cooperative banks and panel B summarizes the evidence for six sub-groups of the credit cooperative banking group. Using the classification scheme of the Deutsche Bundesbank, the credit cooperative sub-groups are commercial cooperatives, rural cooperatives, Raiffeisen banks, Sparda banks, PSD banks (Post-, Spar-und Darlehensvereine), and civil servants banks. We deem this distinction necessary to control for banking group differences in the balance sheet structure and for differences in the type of customer.

\footnotetext{
${ }^{14}$ For 1992:1-2002:4, the share of bank lending to total assets was on average equal to 34 percent, 13 percent, and 8 percent for commercial, credit cooperative, and savings banks, respectively.
} 
-Insert Table 2 here-

A comparison of the mean squared values in Table 2 illustrates that the hypothesis of equal means can be rejected for all bank characteristics and for each banking group sample. The evidence, thus, points to statistically significant differences in the balance sheet structure of banking groups. This, in turn, suggests that conclusions regarding the bank lending effects of monetary policy changes are sensitive to the choice of banking group. To control for this possibility, we will therefore estimate industry-specific bank lending functions by explicitly allowing for individual 'sub-group' effects.

\subsection{The Industry Structure of Bank Loan Portfolios}

So far, the description of the structure of the German banking sector is confined to the distribution of lending to the grand total of industries. This section extends the analysis in that it stresses the industry structure of bank credit portfolios. Table 3 reports lending to industry $\mathrm{i}$ in total lending by banking group for eight industries at the one-digit industry level (main industries) and for nine industries at the two-digit industry level (manufacturing subgroups). Given the focus of the present paper, we only stress the distribution of aggregate and short-term lending as provided by commercial banks (big banks, regional, and private banks) and by the primary institutions of the savings and credit cooperative banking group.

-Insert Table 3 here-

The statistics in Table 3 point to cross-industry differences in the distribution of bank credit. Banks predominantly lend to industries which account for the largest share of output in the aggregate economy: the service, wholesale and retail trade, and manufacturing industry. Cooperative, savings, and commercial banks hold on average, respectively, 69 percent, 81 percent, and 89 percent of their bank loan portfolio with these sectors. Approximately half of these shares is accounted for by lending to the service sector as the most important recipient of bank credit.

As regards the remaining main industries, the volume of bank credit tends to be more evenly distributed across sectors. Agriculture and construction primarily obtain bank finance from the credit cooperative banking group, with rural credit cooperatives and Raiffeisen banks being the primary source of bank finance. ${ }^{15}$ The importance of credit cooperatives for agriculture and construction reflects the regional character of (i) credit cooperatives and (ii) agricultural and constructing firms: lenders and borrowers confine their activities to a particular local area. In

\footnotetext{
${ }^{15}$ Raiffeisen banks and rural credit cooperatives grant 26 (19) percent and 16 (12) percent of aggregate (short-term) credit to agriculture, respectively. In comparison, the corresponding number for commercial credit cooperatives is 6 (5) percent. For construction, the cross-banking group differences are less pronounced. Raiffeisen banks and rural credit cooperatives hold 14 (19) percent and 12 (16) percent of aggregate (shortterm) loans with construction, respectively. Commercial credit cooperatives grant 12 (15) percent of bank credit to construction.
} 
adopting a regional focus, credit cooperatives have superior knowledge of local market conditions which facilitates assessments regarding local economic prospects and the creditworthiness of potential debtors.

The share of bank credit is on average smallest for the finance and insurance industry. One possible explanation for this relationship are large operating surpluses in the finance sector which reduce the need for external finance in general and bank finance in particular. ${ }^{16}$ Next to the finance industry, the energy sector also receives comparatively little credit from commercial banks and from the primary institutions of the savings and credit cooperative banking group. Although not reported in Table 3, the Land banks are an important source of finance to the energy sector. For the period 1992-2002, 12 percent of total lending by Land banks was directed towards the energy sector, with short- and long-term bank credit accounting for 28 and 60 percent, respectively. The importance of Land banks as source of long-term finance to the energy sector is attributable to the components of this sector: mining and quarrying; electricity, gas, and water supply. Given the importance of each of these sub-sectors for the functioning of the economy, general interest is with the maintenance and improvement of the underlying infrastructures. Maintenance requires large fixed expenditures, while infrastructure investment involves costs which tend to be sunk. In order to encourage investment, Land banks grant favorable access to especially long-term finance even though investment per se might not be profitable.

Turning to the sub-sectors of the manufacturing industry, lending to each of the sectors only accounts for a small share of total bank credit. Again, the share of bank credit to each sector is positively related to its size in the aggregate economy. Furthermore, lending to manufacturing sub-sectors tends to be unevenly distributed. The share of bank credit is comparatively small for the coke and chemicals, rubber and plastic, and non-metallic mineral goods producing sector. However, it is relatively large for the wood and paper, machinery and transport equipment, food, and metals producing sector. In fact, lending to these sectors is of approximately the same magnitude as lending to the finance and transport sector.

\subsection{What Explains Differences in Bank Lending?}

As stated, the present paper determines whether changes in bank lending can be explained by industry effects and/or banking group effects. In order to gain a first understanding as to the relative importance of banking groups and industries as source of variation in the distribution of loans across industries, we compute two-way ANOVA test statistics. Table 4 reports the results of the analysis of variance which is defined for the null hypothesis that the volume of bank credit does not differ across either banking groups or industries. We compute the test statistics for the main banking groups and for the sub-sectors of the credit cooperative banking group. Furthermore, we report evidence for industry samples with and without the sub-sectors of the manufacturing industry.

\footnotetext{
${ }^{16}$ For the time period 1992-2002, the share of operating surplus to value added amounts to 51 percent with a standard deviation of 2.30 percent (own computation using the OECD's STAN database for Industrial Analysis). In comparison, operating surplus accounts for at most 31 percent of value added for the remaining industries.
} 
-Insert Table 4 here-

The evidence indicates that the null hypothesis of equal means can be rejected at the level of the industry and the banking group. That is, industry-specific bank lending differs across industries as well as across banking groups. This result holds for aggregate and short-term bank credit and for the main banking groups and the sub-sectors of the cooperative banking group. Even though the volume of bank credit differs across industries as well as across banking groups, industries are the more important source of variation. This is suggested by the F-value for the industry effect which is much larger than the corresponding value for the banking group effect. These findings point to cross-industry heterogeneities in bank credit demand which are likely to be determined by structural and cyclical industry characteristics.

Besides industry-specific structural factors, bank lending might also be influenced by regional factors. This section concludes by testing for regional effects in bank lending. Savings banks, credit cooperatives, and small commercial banks confine their business to narrow local areas. Cooperatives and small commercial banks are locally constrained by sheer size, whereas savings banks are prohibited from crossing local borders by the principle of regional demarcation. Because the industry structure differs at the level of German states (Bundesländer) and at the regional level for East- and West-Germany, the regional focus in banking may also explain cross-bank differences in the industry composition of credit portfolios.

In order to determine the relative importance of regions and banking groups as source of differences in the industry structure of bank credit, two-way ANOVA test statistics are constructed for the hypothesis that bank lending is the same across regions and banking groups. Table 5 contains the results for East- and West-Germany and for the three main banking groups. The evidence for the German states and for the sub-groups of the credit cooperative banking sector is not reported because the results do not differ qualitatively from those for East- and West-Germany or for the main banking groups. Furthermore, because the results tend to be robust across industries, we only report the evidence for composites of industries and not for each individual sector. ${ }^{17}$

-Insert Table 5 here-

The entries in Table 5 point to the existence of discernible cross-banking group and crossregion dissimilarities in bank lending. Even though differences in bank lending are attributable to both banking groups and regions, the banking group effect dominates the regional effect. This conclusion arises from the observation that the F-value for the banking group effect is much larger than the F-value for the regional effect. Regional factors, hence, appear to be a less important determinant of bank lending, while banking-group-specific factors clearly matter.

\footnotetext{
${ }^{17}$ See the notes to Table 5 for the definition of the industry samples.
} 


\subsection{Industry Determinants of Bank Lending}

Motivated by the importance of industry effects as source of industry bank lending, this section discusses possible determinants of industry-specific bank lending related to structural properties of industries. Industry-specific cyclical determinants of bank lending will be discussed in section $6 .{ }^{18}$ We identify possible structural determinants of bank lending by determining the degree of correlation between the share of bank credit to industry $i$ and either industry size, firm size distribution, openness to trade, a measure of internal funds of finance, and proxy variables of capital intensity. In order to avoid that the correlation coefficients are confounded by scale effects, the degree of correlation is determined for the ratio of lending to industry i over lending to the grand total of industries.

Considering industry size, we test whether the relative importance of industries in an economy affects the industry composition of a bank's loan portfolio. For absolute measures of industry size and bank credit volume, the relationship between industry size and bank credit volume is unambiguously positive: banks grant more credit to large rather than small industries. For relative measures of industry size, the relationship may go in either direction. On the one hand, industries which are large relative to the aggregate may obtain comparatively more bank credit. This relationship is likely to hold for young and growing industries whose promising growth prospects are associated with profitable investment projects. Because entrepreneurial industries lack internal funds of finance in presence of investment opportunities, the share of lending to these industries is likely to be higher in comparison to mature and well-established industries. On the other hand, relatively large industries may receive a comparatively small share of bank lending. This relationship is likely to apply to mature or declining industries whose financing needs are largely covered by internal funds of finance or whose external financing needs are low because of poor investment opportunities. In the present paper, our relative measure of industry size is the ratio of value added of industry $i$ to value added of the grand total of industries.

Capital intensity is included to control for the view that the need for external finance increases with the capital intensity of production. External financial funds are required to meet the costs associated with replacing depreciated capital, adjusting existing capital, or installing new capital. The costs of finance are, hereby, heavily dependent on the monetary policy stance through its effect on the opportunity cost of capital investment. This link is emphasized by the interest rate channel of monetary policy. ${ }^{19}$ Because the strength of the interest rate effects depends on industry structure, the interest rate channel is also known as the industry channel. ${ }^{20}$ The literature on industry effects of monetary policy favors several measures of capital intensity. ${ }^{21}$ We use industry-specific capital intensity measures which appear to be time-invariant and, hence, robust to cyclical fluctuations: the ratio of the capital stock to employment $(\mathrm{K} / \mathrm{N})_{\mathrm{i}}$ and the ratio of employment to real value added $(\mathrm{N} / \mathrm{Y})_{\mathrm{i}}$ in industry $\mathrm{i}^{22}$

\footnotetext{
${ }^{18}$ We only report the results for structural characteristics because data limitations in terms of frequency prevent us from using the data in the dynamic panel estimation.

${ }^{19}$ See, e.g., Kashyap and Stein (1995), Mojon (2000), and Kuttner and Mosser (2002).

${ }^{20}$ See, e.g., Dedola and Lippi (2005), Peersman and Smets (2005).

${ }^{21}$ See Hayo and Uhlenbrock (2000), Peersman and Smets (2005), and Dedola and Lippi (2005).

${ }^{22}$ We also use the ratio of the stock of capital over output as proxy variable of capital intensity. Because the results are qualitatively the same as those for the ratio of the stock of capital over employment, we do
} 
We include firm size to test for a possible inverse relationship between firm size and the need for bank finance. The Deutsche Bundesbank (2000) uses bank finance needs as synonym for bank dependence and explains the negative relationship between the demand for bank finance and firm size by stressing the transaction costs and information asymmetries associated with bond-based financing. Transaction costs such as brokerage and underwriting fees are largely independent of the amount of bonds issued and, thus, render only large amounts of bond issues feasible from a financial point of view. Information asymmetries arise between the issuer and potential holder of bonds. In order to mitigate asymmetric information problems, sufficient information on the bond issuing company needs to be easily available. Because large firms are subject to more stringent regulation, disclosure rules, and reporting standards than small firms, such information is more freely disseminated for large than for small companies and the degree of information asymmetries, hence, decreases with the size of firms. As a consequence, the ability to substitute bank lending by bonds increases with firm size and the degree of bank dependence diminishes with firm size. ${ }^{23}$ These relationships cause business size to be typically associated with the credit channel of monetary policy.

In Germany, the difference in the relative importance of bonds and bank credit also rests on relationship banking and the corresponding notion of banks being the housebank to firms. The housebank principle facilitates the flow of information between creditors and debtors, establishes confidence, and reduces asymmetric information problems. Tight bank-firm relationships, thus, leave banks with a comparative advantage regarding risk assessment, monitoring, and information asymmetries and lower the costs of bank-finance relative to nonbank finance. $^{24}$ In view of these relationships, we hypothesize that banks lend more to industries with a large share of small firms. In order to test this hypothesis, we use the share of small firms in industry $i$ to approximate the distribution of firm size.

Besides firm size distribution, we approximate the need for external finance by including the industry-specific ratio of operating surplus over value added as proxy variable of internal funds of finance or working capital. ${ }^{25}$ Credit market imperfections cause the expected relationship between internal funds of finance and bank credit to be negative. The underlying argument is similar to that of the net worth effect in section 1 and predicts a mismatch between credit demand and credit supply.

Finally, we include openness to trade in order to determine the extent to which industry-specific exposure to trade and exchange rate fluctuations affects loan demand. Whether lending by banks to industries open to trade responds more or less to changes in industry production and industry price depends on the argumentation. On the one hand, open industries may not

not report the corresponding evidence.

${ }^{23}$ Also see Deutsche Bundesbank (1998a, 2002a) and Elsas and Krahnen (2004) for a discussion of the bank dependence of small- and medium-sized companies.

${ }^{24}$ See Harhoff and Körting (1998) for empirical evidence which lends support to the importance of housebank relations and relationship lending in Germany. The underlying analysis does not distinguish between the size of banks and firms involved in a long-term relationship.

${ }^{25} \mathrm{An}$ alternative and more direct measure of internal finance is cash flows. However, because industryspecific information on cash flow or the components thereof (earnings, interest payments, taxes, dividend payments, depreciation) are unavailable, we use operating surplus as simple measure. 
adjust loan demand in response to output growth or inflation by as much as closed industries if cyclical changes in product demand abroad and at home are not synchronous but occurring at a periodic lag. This smoothes cash flows, and, therefore, the cyclical demand for bank credit. On the other hand, lending to open industries might be more sensitive to changes in domestic output and inflation when domestic and foreign business cycles are dis-concordant and when real exchange rate developments cause adverse developments in international competitiveness.

Table 6 reports the degree of correlation between short-term lending and structural industry characteristics for the period 1992-2002. ${ }^{26}$ The results for aggregate lending are not reported because they do not differ qualitatively from those for short-term lending. In order to match the frequency of bank-specific and industry-specific data, the quarterly bank level data are expressed in annual terms. Furthermore, we aggregate the micro data over all banks in order to avoid that the significance properties of the correlation coefficients are driven by the number of observations. The correlation coefficients build on information for seven industries at the one-digit industry level and nine sub-sectors of the manufacturing industry. We obtain the data on industry characteristics from the New Cronos database of Eurostat and from the STAN database for Industrial Analysis of the OECD. ${ }^{27}$ The firm size data refer to the size class of 1 to 19 employees; a size category which corresponds to the definition of small firm size (cf. Loveman and Sengenberger, 1991; Henrekson and Johansson, 1999). The bank lending data are obtained from the quarterly borrower statistics of the Deutsche Bundesbank. ${ }^{28}$ The degree of correlation between industry characteristics and bank lending is computed for the variables' ratio of industry $i$ to the grand total of industries for the aggregate banking group, the subgroups of the credit cooperative banking sector, and for commercial and savings banks. ${ }^{29}$

-Insert Table 6 here-

The evidence suggests that banks grant relatively more credit to industries which are comparatively large. This suggests that the credit portfolio of banks is biased towards large industries when measured in absolute as well as relative terms. For Germany, the relationship between relative industry size and the share of bank lending might be influenced by the service industry which accounts for the largest share of value added and bank lending. However, when we exclude this sector, the linkage between the share of bank lending and relative industry size even strengthens. ${ }^{30}$ That is, relatively large industries obtain a larger share of bank credit beyond the effect associated with the service industry.

Considering the relationship between the relative degree of capital intensity of industry production and the share of bank credit, banks lend comparatively less to capital intensive industries.

\footnotetext{
${ }^{26}$ Because of data availability constraints, the firm size correlation coefficients are constructed for the period 1999-2000.

${ }^{27}$ See appendix A.1 for details.

${ }^{28}$ Section 5 provides additional details.

${ }^{29}$ The results are robust to the definition of industry characteristics. Expressing the industry characteristics in absolute rather than in relative terms does not affect the conclusions.

${ }^{30}$ The results are not reported but available on request. The correlation coefficients for the remaining industry characteristics tend to be robust to the exclusion of the service sector.
} 
This finding is robust to the choice of capital intensity measure and is particularly strong for the sub-groups of the credit cooperative sector. The negative link between relative capital intensity and the relative share of bank lending is counterintuitive if one considers the costs of physical capital investment which asks for financial means. The Deutsche Bundesbank (1996) suggests that the inverse relationship between the volume of bank lending and capital intensity is due to precautionary lending on the part of banks to capital intensive industries. Precaution arises because lending to capital intensive industries is considered to be characterized by higher probabilities of loan losses than lending to capital extensive industries.

As regards the evidence for firm size, the correlation coefficients have the expected positive sign which points to an inverse relationship between firm size and the share of bank credit. According to the European Commission (2003), this reflects the greater need of relatively small firms for working capital. ${ }^{31}$ Unfortunately, the correlation coefficient is statistically insignificant which leaves the relationship indicative rather than affirmative. We attribute the insignificance to the small number of data points on firm size. Next to firm size, the correlation coefficients for operating surplus and openness also tend to be insignificant. The exception concerns lending by Raiffeisen banks which grant relatively more credit to open industries and lending by commercial banks which grant less credit to industries with relatively high operating surplus. However, the low significance properties again cause this relationship to be suggestive.

Overall, the correlation coefficients provide ambiguous evidence as to the existence of a relationship between structural industry characteristics and the share of bank credit to individual industries. Significant relationships are confined to relative industry size and to the proxy variables of relative capital intensity. Alternative industry characteristics do not have a significant effect on the industry composition of a bank's credit portfolio. We will show in section 6 that industry effects of bank lending arise from cyclical factors related to industry output and industry prices.

\subsection{Synthesis}

Summarizing, the descriptive analysis shows that banks structure their credit portfolio around industries and that banking groups differ in their exposure to industries. The differences are mainly attributable to effects associated with banking groups and industries, but less to regional effects. In view of these findings, differences in the responsiveness of lending to changes in loan demand and monetary policy are, therefore, expected to reflect banking group effects and industry effects. Given the evidence from section 3.1 and 3.2, the banking-group effects are likely to reflect cross-banking group heterogeneities in the industry structure of bank credit portfolios and in the characteristics of the average bank. Cross-industry differences in the relative share of bank lending are attributable to cross-industry differences in structural characteristics like capital intensity and relative industry size, but not to firm size distribution.

\footnotetext{
${ }^{31}$ The descriptive evidence in European Commission (2003) illustrates that (small) businesses in manufacturing, transport and communication, and wholesale require more bank credit than (small) firms in other sectors.
} 


\section{$4 \quad$ Empirical Model}

The remainder of this paper abstracts from structural industry characteristics and stresses industry-specific cyclical determinants of bank credit demand as factors which have a strong effect on bank lending to industries. Besides cyclical credit demand factors, we will also stress the role of monetary policy as determinant of industry-specific bank lending and test for credit channel effects of monetary policy via bank lending. We ask whether differences in the bank lending effects of credit demand and monetary policy are accounted for by industries or by banking groups. The corresponding evidence will show whether the industry structure of bank credit portfolios or the structure of the German banking sector influence the effectiveness of monetary policy and the performance of industries through the availability of industry-specific bank credit. Furthermore, we test whether conclusions are robust to the choice of aggregate and short-term bank credit. The remainder of this section presents the industry-specific bank lending functions that will be used to identify the industry and banking group effects of bank credit demand and monetary policy. Within this framework, we also discuss the methodological approach used to estimate the dynamic panel model.

\subsection{Empirical Estimation Framework}

In order to identify the response of bank lending to changes in bank credit demand and monetary policy, we estimate a set of bank lending functions using the dynamic panel estimation framework of Ehrmann et al. (2003), Worms (2003), and Gambacorta and Mistrulli (2004). Although we use the same structural estimation framework, the analysis adds to the existing work by exploring the industry dimension of bank lending. Equation (1) describes the empirical bank lending function for industry $i$ and bank $b$.

$$
\begin{aligned}
\Delta \mathrm{L}_{\mathrm{bi}, \mathrm{t}}= & \alpha_{\mathrm{b}}+\sum_{\mathrm{j}=1}^{\mathrm{p}} \beta_{\mathrm{ij}} \Delta \mathrm{L}_{\mathrm{bi}, \mathrm{t}-\mathrm{j}}+\sum_{\mathrm{j}=1}^{\mathrm{p}} \gamma_{1 \mathrm{j}} \Delta \mathrm{r}_{\mathrm{m}, \mathrm{t}-\mathrm{j}}+\sum_{\mathrm{j}=1}^{\mathrm{p}} \gamma_{2, \mathrm{ij}} \Delta \mathrm{IP} \mathrm{P}_{\mathrm{i}, \mathrm{t}-\mathrm{j}}+\sum_{\mathrm{j}=1}^{\mathrm{p}} \gamma_{3, \mathrm{ij}} \Delta \text { Price }_{\mathrm{i}, \mathrm{t}-\mathrm{j}}+ \\
& \gamma_{4} \mathrm{X}_{\mathrm{b}, \mathrm{t}-1}+\sum_{\mathrm{j}=1}^{\mathrm{p}} \gamma_{5 \mathrm{j}} \mathrm{X}_{\mathrm{b}, \mathrm{t}-1} \Delta \mathrm{r}_{\mathrm{m}, \mathrm{t}-\mathrm{j}}+\epsilon_{\mathrm{bi}, \mathrm{t}} .
\end{aligned}
$$

The coefficient $\alpha_{\mathrm{b}}$ is a bank-specific intercept which is included to allow for fixed effects across banks and $\epsilon_{\mathrm{bi}, \mathrm{t}}$ is an i.i.d. random variable with zero mean and constant variance, i.e., $\mathrm{N} \sim\left(0, \sigma_{2}\right)$. $\mathrm{L}_{\mathrm{bi}, \mathrm{t}}$ denotes lending by bank $\mathrm{b}$ to industry $\mathrm{i}$ at time $\mathrm{t}$, with $\mathrm{b}=1, \ldots, \mathrm{N}_{\mathrm{b}}$ and $\mathrm{t}=1, \ldots, \mathrm{T}$. The autoregressive parameters $\beta_{\mathrm{ij}}$ are assumed to be the same across banks, but heterogeneous across industries. Furthermore, they may differ across banking groups. In order to control for cross-banking group differences, we estimate the model for individual banking groups.

$\Delta$ is the first $\log$-difference operator of variable $\mathrm{V}$ defined as $\Delta \equiv \log \mathrm{V}_{\mathrm{t}}-\log \mathrm{V}_{\mathrm{t}-1}$. With the exception of the money market interest rate, the first log-difference transformation is applied to all variables. The money market interest rate enters in first differences. Ehrmann et al. (2003) motivate the first-difference structure of the empirical model by stressing that the monetary 
policy effect on bank lending is confined to new loans. They, hence, interpret the first logdifference of bank credit as flow variable and introduce the level of loans as stock variable. When suggesting this measure of new loans, Ehrmann et al. (2003) fail to recognize that the first difference is an imperfect measure of new bank loans since it reflects the net effect of new loan issues and loan repayments. Unfortunately, the present study can only acknowledge this shortcoming, but cannot resolve it because of data unavailability. As a consequence, reductions in the volume of loans outstanding may reflect a decline in new loan issues or a net increase in loan repayments.

$\mathrm{IP}_{\text {it }}$ approximates industry-specific output at time $\mathrm{t}$ which serves as a measure of cyclically determined industry-specific loan demand. Price ${ }_{i t}$ denotes the industry-specific price at time $t$ and is included to capture cyclical fluctuations in industry-specific price developments. These variables do not only determine the external financing needs of industries, but also influence the perceptions of banks as to the riskiness of industries. Monetary policy actions are represented by the change in the three-months money market interest rate $\Delta r_{m}$. We assume that the interest rate is strictly exogenous to bank lending. ${ }^{32}$ In order to identify the bank lending effects of monetary policy, the money market interest rate $\left(r_{m, t-j}\right)$ at time $t-j$ is interacted with bank characteristics $\left(X_{b, t-1}\right)$ at time $t-1$. The vector of bank-specific characteristics $X_{b}$ includes asset size (TA), liquidity $(A)$, and capitalization $(K)$ at time $t-1$. Bank characteristics are introduced with one lag to avoid an endogeneity bias (cf. Kashyap and Stein, 1995, 2000; Ehrmann et al., 2003; Worms, 2003; Gambacorta and Mistrulli, 2004). Appendix A.2 contains a formal definition of the bank characteristics which are normalized with respect to the average across all banks and time.

Worms (2003) and Ehrmann and Worms (2004) show that the tight relationship between the primary and head institutions of the savings and credit cooperative banking sector causes bank asset size to be an inappropriate proxy variable of the bank lending effects of monetary policy. One explanation is that interbank operations enable small banks to shield their loan portfolio and funding possibilities against monetary policy shocks by providing a relatively unconstrained access to central bank money. In that sense, the interbank market helps to redistribute liquidity within the banking sector from banks with excess liquidity to banks in need of liquidity. This, in turn, moderates financing constraints for small banks. As a consequence, the interest rate sensitivity of small bank lending does not have to be higher than that of large banks. Bank size might also be an inappropriate measure of information asymmetries because savings banks as well as credit cooperatives back their funds with mutual guarantees. This serves to recapitalize banks and creates a type of insurance scheme for creditors in case of bank insolvency. The existence of these insurance schemes implies that information asymmetries may not affect the lending behavior of banks. Size, consequently, appears to be an inadequate variable to identify the loan supply effects of monetary policy and alternative measures might be bank capitalization or bank liquidity.

The present model employs two measures of bank liquidity. The first 'broad' definition computes bank liquidity as the ratio of cash plus securities plus short-term interbank claims over total bank assets. This measure controls for the extent to which banks have access to in-

\footnotetext{
${ }^{32}$ See Worms (2003) for empirical evidence as to the robustness of the interest rate response of bank lending to the assumption of exogeneity.
} 
terbank finance. The second 'narrow' definition of liquidity takes into account the finding by Worms (2003) and Ehrmann and Worms (2004) according to which short-term interbank claims drive liquidity effects and dwarf asset size effects. We follow Worms (2003) and exclude short-term interbank claims from the 'narrow' measure of liquidity. In order to capture the importance of interbank finance flows, short-term interbank claims also enter the empirical analysis as an independent variable. In line with the other bank characteristics, interbank claims are normalized with respect to the average across all banks and time.

We hypothesize the coefficient estimates in model (1) to enter with the following signs. Motivated by the negative effects of higher interest rates on bank reserves, we expect bank lending to decline in response to a monetary contraction. The distributional effects of monetary policy are anticipated to be such that the response of bank lending to monetary policy changes is less pronounced for larger, more liquid, and better capitalized banks. This holds if the coefficient on the interaction term between each bank characteristic and the interest rate is positive. Ambivalent conclusions prevail with respect to the expected effect of industry output growth on bank lending growth. On the hand, good economic conditions raise the number of investment projects with positive net present value and, hence, the demand for bank finance. On the other hand, economic growth stimulates internal cash flows which may lower credit demand. Because evidence in favor of a negative relationship between output and bank lending is hardly existing, the long-run coefficient on output growth is expected to be positive. ${ }^{33}$ Finally, industry inflation is anticipated to stimulate bank lending growth. This relationship is attributable to the negative effect of positive price changes on real income and, hence, real cash flows. ${ }^{34}$

The analysis does not explicitly account for merger-driven changes in the German banking structure and, hence, does not control for the effects of mergers on the individual characteristics of the merging banks. The appropriateness of this approach is suggested by Worms (2003) who finds the long-run bank lending effects of monetary policy to be the same for samples which do not control for mergers and for samples which treat a merged bank as single bank for the pre- and post-merger sample period. Besides, implementation lags between the time a merger is officially announced and the time a merger is legally realized makes it difficult to determine the date of a merger.

\subsection{Methodology}

The system in equation (1) represents a fixed effects dynamic (unbalanced) panel with large $\mathrm{T}$ and large $\mathrm{N}$. Lagged values of the dependent variable are included to control for omitted variable and endogeneity bias. Because the lagged dependent variable is correlated with the error term, dynamic panel models are typically not estimated with the static panel fixed effects estimator. Doing so would introduce a finite sample bias of order $\frac{1}{\mathrm{~T}}$ for $\mathrm{N} \rightarrow \infty$ and fixed T (see

\footnotetext{
${ }^{33}$ See De Bondt (1998), Worms (2003), Ehrmann et al. (2003), and Gambacorta and Mistrulli (2004) for evidence in favor of a positive relationship between bank lending and output. Altunbaș, Fazylov, and Molyneux (2002) report a positive output coefficient for medium-sized and undercapitalized banks and a negative coefficient for small-sized and under- or overcapitalized banks in Germany.

${ }^{34}$ Ehrmann et al. (2003) and Gambacorta and Mistrulli (2004) report evidence of a positive price effect on bank lending.
} 
Nickell, 1981; Kiviet, 1995). In order to avoid biased and inconsistent estimates, Arellano and Bond (1991) suggest the use of a generalized method of moments (GMM) estimator. Recent studies have challenged this method. Blundell and Bond (1998) and Blundell, Bond, and Windmeijer (2000) have shown that the first-differenced GMM estimates are biased downwards in the direction of the within-group estimates and Alvarez and Arellano (2003) show that the GMM estimator is close to the fixed effects estimator for large T. Furthermore, Jung (2005) illustrates that Arrelano and Bond's (1991) test of serial residual correlation may build on inconsistently estimated residuals. Because these are used to decide on the optimal overidentifying restrictions, coefficient estimates are likely to be inconsistent.

In view of these points and given a comparatively large set of data points in the time dimension, we estimate the dynamic panel model by using the fixed effects estimator. Besides, the use of the fixed effects estimator is also motivated by the evidence from the Hansen J-statistic according to which the over-identifying restrictions in the present set of GMM estimations are invalid regardless of the instrumentalization. In order to ensure that the presence of autocorrelation in the residuals $\epsilon_{\text {it }}$ does not result in inconsistent and inefficient estimators, we compute White-period standard errors (Arellano, 1987) which are robust to arbitrary serial correlation and time-varying variances in the residuals. We test for the existence of first-order and second-order serial autocorrelation by regressing the within regression residuals against their one- and two-period lag. The underlying model allows for fixed effects and White-period standard errors. ${ }^{35}$

\section{$5 \quad$ Data}

Ideally, the analysis of industry-specific bank lending effects of changes in credit demand and monetary policy would build on firm level as well as bank level data. Bank level data allow for the identification of the credit channel effects of monetary policy through bank lending and firm level data allow for assessments regarding the operation of a credit channel through balance sheet effects. Even though firm level data are available from the corporate balance sheet statistics of the Deutsche Bundesbank, they are not useful for our purpose because they are only available at an annual frequency and subject to a large firm bias. ${ }^{36}$ Given the unavailability of firm level data, we determine the bank lending effects of changes in credit demand and monetary policy for industry aggregates. We compile industry data for 17 industries which include eight industries at the one-digit industry level and nine industries at the two-digit industry level. The latter are sub-sectors of the manufacturing industry (see Appendix A.1).

Bank level data on bank-specific balance sheet data and bank-specific credit supply to individual industries is respectively obtained from the quarterly borrower statistics and monthly bank balance sheet statistics of the Deutsche Bundesbank for the period 1992-2003. Because data

\footnotetext{
${ }^{35}$ Note, the conclusions regarding the existence of serial autocorrelation are robust to the way in which the first- and second-order autocorrelation coefficient is computed. A simple least-squares estimator without fixed effects and White-period standard errors produces comparable results.

${ }^{36}$ See Deutsche Bundesbank (1998b) for details.
} 
in 2003 display patterns which are unreconcilable with those in earlier years, we confine the analysis of quarterly data to the period 1992:1-2002:4. The bank-specific balance sheet and lending data display seasonal patterns. For each bank, these are removed by means of the centered-moving average method. This is an admittedly simple adjustment procedure which can be criticized for ignoring, for example, working day and leap year effects. However, it is the preferred method in the present analysis because it is applicable despite the large number of cross sections. Furthermore, a comparison of the seasonally adjusted and non-adjusted series shows that the centered moving average procedure captures seasonal fluctuations well.

Information on industry production and industry prices is available from the New Cronos database at a monthly frequency for most industries. For some industries, industry output is approximated with industry value added. The corresponding data are provided by the German federal statistical office. The monthly data on industry output and prices are converted into quarterly data to match the frequency of the bank lending data. While data on industry output is directly obtained for the sample period 1992:1-2002:4, information on industry prices is only available as of 1995:1. In order to identify the 1992:1-1994:4 values, we regress the industryspecific price index against a constant and the contemporaneous value of the aggregate price index and use the coefficient estimates from ordinary least squares (OLS) to extrapolate the missing values on industry-specific prices. Industry prices for the wholesale and retail trade, finance and insurance, transport and communication, and service sector are not available from the New Cronos database. Instead, we construct them using information on nominal and real value added from the German statistical office for the whole sample period 1992:1-2002:4. ${ }^{37}$

The New Cronos database and the corporate borrower statistics occasionally differ in terms of industry aggregation. In particular, the corporate borrower statistics tend to refer to composites of industries rather than to individual units. In order to adopt the same level of industry aggregation, the New Cronos data on industry production and industry characteristics are also combined across some industries. The composite indices are constructed by controlling for the relative importance of the single industries in the composite. Limited by data availability, the weights are approximated as the 1992-2002 ratio of value added of industry i to aggregate value added of the industries included in the composite. Since the weights are time-invariant, the use of the 1992-2002 average as weight seems to be innocuous.

We estimate the industry-specific bank lending models for aggregate and short-term bank credit supply. The focus on short-term lending is motivated by existing studies which point to an immediate response of short- rather than long-term lending to changes in monetary policy (Gertler and Gilchrist, 1993; Kakes and Sturm, 2002). Short-term loans are also likely to respond more to cyclical fluctuations in industry output and prices and to changes in monetary policy since they are renewed at shorter intervals than long-term or average loans. The importance of short-term credit can be explained in terms of expectations. If firms belief that output growth, inflation, and interest rates are mean stationary, they will expect an increase in inflation or interest rates, and a decline in output growth today to be followed by an opposite movement tomorrow. Firms, therefore, also expect real income and, hence,

\footnotetext{
${ }^{37}$ Note, the German statistical office reports data on nominal and real value added jointly for the (i) wholesale and retail trade sector and (ii) transport and communication sector. Unfortunately, we cannot disentangle the industry-specific price for each of these sectors, but have to rely on the composite price measure.
} 
internal funds of finance to evolve as a predictable mean-stationary long-term growth path. As a consequence, they are more likely to cushion temporary changes in internal funds with shortrather than medium- or long-term external credit. ${ }^{38}$. As regards an increase in interest rates, short-term lending may also increase because firms shorten the maturity of debt in anticipation of lower future interest rates.

Besides these considerations, we also focus on short-term lending because long-term credit is determined by factors which cannot easily be constructed given the available information. For example, long-term financing needs depend on strategic considerations and expectations regarding future changes in industry activity and prices. Because data on, e.g., expected output and prices are unavailable at a low level of industry aggregation, we cannot estimate model (1) for long-term lending without incurring the risk of reporting biased and inconsistent estimates due to an omitted variable bias. Surely, the omitted variable bias may also affect the results for the model with aggregate lending, where aggregate lending is computed as the sum of short-, medium-, and long-term bank credit. The evidence on aggregate lending should, therefore, be viewed as reference point to judge the plausibility of the results for short-term lending.

In order to ensure the reliability of the empirical results, the quarterly data are screened along different lines. Firstly, the data are checked for outliers. Outlier detection concerns the behavioral relationship between variables as well as the distribution of variables. One behavioral relationship concerns the need of banks to meet their balance sheet constraint. For the requirements that total assets equal total liabilities, the study keeps all but 5 data points. ${ }^{39}$ Another relationship is defined as the need to have positive entries for credit supply and total assets. In the present sample, at most 18 data points for industry-specific loans and 47 data points for total assets do not meet the non-negativity constraint. These observations are excluded from the sample.

As concerns the distribution of variables, the outlier detection procedure is typically realized for variables in levels. The exception concerns the volume of bank credit and total bank assets. In order to avoid the exclusion of very large and very small banks on the ground of sheer size, the outlier detection procedure for total assets and the volume of bank credit is implemented for their first log-differences. ${ }^{40}$ Regardless of the variable, outliers are detected by using the sequential outlier rejection (SOR) algorithm described in Corney (2002). In contrast to standard methods like the z-score or box plot method, this outlier detection procedure adopts a sequential approach which accounts for the effect of outliers on the standard error in the sample. Furthermore, the SOR approach does not assume the normal distribution of banks at any point in time. This property is particularly valuable since the hypothesis of normal distribution of banks can be rejected for all sampled variables (see Table 1 and Table 3 ). The SOR algorithm requires the data to be repeatedly clustered using any clustering algorithm. The present analysis uses k-means clustering for each of the main banking groups, with $\mathrm{k}=2 .{ }^{41}$

\footnotetext{
${ }^{38}$ See Kakes and Sturm (2002) and Gambacorta and Mistrulli (2004) for the effect of interest rate changes on the demand for short-term finance.

${ }^{39} \mathrm{~A}$ data point is a single time observation associated with an individual bank (e.g. the observation associated with bank $\mathrm{i}$ in 1992:1).

${ }^{40}$ See Worms (2003) for a similar procedure.

${ }^{41}$ The large number of observations and computer limitations preclude the definition of more than two
} 
For each repetition, the sum-squared error for k-means is computed which describes the sumsquared deviation of each data point in the sample to the nearest cluster center. The data point which contributes most to the sum-squared error for k-means is excluded from the sample.

For each point in time and each banking group, the clustering algorithm is iteratively applied to the data set. The number of iterations is roughly equal to 5 percent of the number of banks at each point in time. ${ }^{42}$ That is, the first step of the procedure treats 5 percent of all banks at each point in time as potential outlier. The second step builds on the iteratively excluded observations from step one and determines the actual number of outliers by using the second difference of the sum-squared error term. Under the assumption that the error rate is driven by outliers, the second derivative is close to zero and the cumulative sum thereof is constant for the sequence of data which excludes atypical observations. In the present paper, we exclude any data point as outliers if it explains more than one percent of the cumulative sum of the second derivative. Similar to other outlier detection methods (e.g., box plot method and z-approach), the choice of threshold is arbitrary.

The analysis is confined to institutions which have the status of a monetary finance institute $(\mathrm{MFI})$ throughout the whole sample period. The restricted focus is necessitated by the change in data definition. Until 1998:4, non-MFl's were treated as financial institutions and the Deutsche Bundesbank borrower statistics reported lending by these institutions to enterprises and households. As of 1999:1, non-MFl's are treated as enterprises and the borrower statistics do no longer report lending by, but credit supply to these institutions. In order to avoid that the definitional change of non-MFl's from being creditors to being debtors may bias the results, we exclude banks with a non-MFI status in any quarter during the sample period. This leads to a loss of 1400 data points from the commercial banking group and 208 data points from the cooperative banking group.

\section{$6 \quad$ Empirical Results}

This section reports the empirical results of the fixed effects dynamic panel estimation. We summarize the bank lending effects of loan demand and loan supply changes by computing the long-run elasticities of bank lending with respect to the explanatory variables in model (1). ${ }^{43}$ The industry-specific long-run coefficients $\alpha_{\mathrm{LR}, \mathrm{i}}$ are defined as the sum of the lags of the variable in question divided by one minus the sum of the coefficients on the lagged bank credit variable: $\alpha_{\mathrm{LR}, \mathrm{i}}=\frac{\sum_{\mathrm{j}=1}^{J} \gamma_{\mathrm{ij}}}{1-\sum_{\mathrm{j}=1}^{J} \beta_{\mathrm{ij}}}$, where $\mathrm{J}=4 .{ }^{44}$ Since the long-run coefficients are a non-linear

clusters.

${ }^{42}$ The number of iterations depends on the availability of data in a given time period and a given banking group. The results are not sensitive to a larger number of iterations.

${ }^{43}$ We follow the existing literature when referring to long-run elasticities (e.g., Deutsche Bundesbank, 2002b; Gambacorta and Mistrulli, 2004; Worms, 2003; Ehrmann et al., 2003). An alternative and more intuitive interpretation views the 'long-run' coefficient as the lasting response of bank lending growth to changes in either bank credit demand or monetary policy.

${ }^{44}$ The properties of the residuals do not change with $\mathrm{J}=5$. 
function of the estimated parameters, we derive the corresponding standard errors by means of the delta method. ${ }^{45}$

The empirical model is estimated for different combinations of banking groups. One sample jointly includes the primary institutions of the commercial, savings, and credit cooperative sector. This group is subsequently referred to as the aggregate banking group. Group-specific effects are captured with banking group dummies for the savings and commercial banking group. However, the dummies turn out to be statistically insignificant in almost all specifications which suggests weak or no banking group effects for savings and commercial banks relative to credit cooperatives. In view of this finding, the subsequent evidence for the aggregate banking group refers to the results from estimations without banking group dummies. We also estimate the model for the aggregate credit cooperative banking sector ${ }^{46}$, with banking dummies for the commercial credit cooperative banking group and Raiffeisen banks. In contrast to the aggregate banking group, the dummies turn out to be statistically significant for most industry bank lending functions.

In order to allow for the possibility of parameter heterogeneity across banking groups, another sample is separately defined for the three main sub-groups of the credit cooperative banking group (i.e., rural, commercial, and Raiffeisen banks) and for savings banks. The importance of parameter heterogeneity was suggested by the ANOVA evidence in section 3.1 which points to structural differences between (i) the savings and cooperative banking group and (ii) the subgroups of the cooperative banking sector and, hence, to panel heterogeneity. When estimating individual models for the savings and credit cooperative banking group, we assume cross-bank homogeneity in the interest rate elasticity of loan demand and, hence, cross-bank similarities in the distribution of bank-dependent and bank-independent customers within each individual banking group. We do not estimate an individual model for the commercial banking group or for the head institutions of the savings and credit cooperative banking sector because they operate product portfolios which differ from those of the local savings and credit cooperative banks. Besides, estimates for an individual sample of commercial banks are not reported since the number of observations and cross sections is low. The fixed number of observations causes the fixed effects estimator and the robust covariance matrix estimates to be inconsistent even though $\mathrm{T}$ is large.

Given the evidence in favor of (weak) regional effects in section 3.3, we also include a dummy variable which discriminates banks by their location in either East- or West-Germany to control for regional structural differences in industry structure and in the degree of concentration of the banking market. As shown by Fischer (2001), local banking markets are more concentrated in East-Germany than in West-Germany. Also, he documents that (i) firms with business in local areas with concentrated banking markets are more bank dependent than firms in less concentrated banking markets and (ii) firms have higher average ratios of bank loans to total assets in concentrated banking markets than in less concentrated banking markets. One may, therefore, hypothesize that the bank lending effects of monetary policy are stronger in East-

\footnotetext{
${ }^{45}$ To conserve on space, we only report the short-run coefficient for the one-period lag of the normalized bank characteristic. The short-run coefficients for the remaining variables are available on request.

${ }^{46}$ The underlying sample combines information on commercial and rural credit cooperatives and Raiffeisen banks.
} 
than in West-Germany. However, the regional dummy turns out to be statistically insignificant in almost all specifications. Because this suggests that structural differences in regional banking markets do not explain bank lending behavior, the empirical results are reported for estimations which do not include the regional dummy.

\subsection{Analysis of Variance Tests}

The representation of the results is complicated by the cross-sectional dimension of the study. To condense the analysis, section 6.1 first reports test statistics of one- and two-way analysis of variance which illustrate the sensitivity of the results to the choice of bank characteristic, the choice of aggregate and short-term lending, and the choice of industry and banking group. The test statistics are computed irrespective of the significance properties of the coefficient estimates. If we would confine the analysis to industries for which significant estimates are reported, ANOVA would not be feasible. Despite the inclusion of insignificant estimates, the results are still deemed to be illustrative. On the one hand, we only compute test statistics for variables for which most industry-specific estimates are statistically significant, i.e., for industry output growth, industry inflation, and the interest rate change. Test statistics are not reported for the interaction terms because of pronounced differences in their statistical significance and sign properties across the different bank lending specifications. On the other hand, the sign and magnitude of insignificant industry-specific coefficient estimates on either industry output growth, inflation, or the interest rate change compares well with those of significant estimates regardless of the choice of bank characteristic.

The remainder of this study does not consider the evidence for the bank lending functions of the metals producing industry. This is because of serial correlation of the residuals in the corresponding estimations which results in biased and inconsistent estimates. The autocorrelation properties do not improve in estimations with alternative lag structure and are robust to the structure of the model.

We first investigate whether the coefficient estimates for industry output growth, inflation, and the interest rate change are influenced by the choice of bank characteristic, i.e., bank asset size, capitalization, liquidity, or short-term interbank claims. Because the results are robust to the choice of banking group and do not differ for aggregate and short-term lending, we only report the results for the aggregate banking group and for short-term lending. ${ }^{47}$ The results in Table 7 (column 3-6) show that the null hypothesis of equal coefficients across bank characteristics cannot be rejected. The choice of bank characteristic, hence, does not significantly affect the long-run sensitivity of bank lending with respect to either industry-specific bank credit demand or the money market interest rate.

-Insert Table 7 here-

We next ask whether the long-run coefficients of the sampled variables depend on the choice of aggregate and short-term bank lending. Because the coefficient estimates are insensitive

\footnotetext{
${ }^{47}$ The results for the remaining banking groups are available on request.
} 
to the choice of bank characteristic, we only report the one-way ANOVA test statistics for bank asset size. The evidence in Table 7 (column 7-10) points to the equality of the long-run coefficients for aggregate and short-term lending. This, in turn, suggests that conclusions regarding the determinants of bank lending growth do not differ for aggregate and short-term credit. ${ }^{48}$ This results holds with respect to all sampled variables.

We conclude the discussion by formally testing whether differences in bank lending effects are accounted for by banking groups or by industries. To this end, we compute the test statistics of a two-way analysis of variance. The banking groups are composed of savings banks and the three main sub-groups of the credit cooperatives sector. The number of industries is determined by the white noise properties of the estimated residuals. We include the eight industries at the one-digit industry level and eight sub-sectors of the manufacturing industry. Given the one-way ANOVA test statistics, we only report the results for short-term lending and bank asset size, noting that the evidence for aggregate lending and the remaining bank characteristics does not differ. ${ }^{49}$ Table 8 summarizes the results.

-Insert Table 8 here-

The analysis of variance shows that differences in the responsiveness of short-term bank lending growth to industry output growth and industry inflation are attributable to industries, but not to banking groups. That is, the evidence stresses discernible industry dissimilarities in the bank lending effects of industry output growth and inflation. In contrast to output growth and inflation, differences in the long-run bank lending effects of interest rate changes are explained by banking groups in industries. However, industry effects appear to be the main source of variation in the bank lending effects of monetary policy. This conclusion builds on the observation that the F-value for the industry effect exceeds the corresponding value for the banking group effect.

\subsection{Evidence from Industry-Specific Bank Lending Functions}

The analysis of variance shows that industries are the main source of differences in the bank lending effects of industry credit demand and monetary policy. In addition, we find the results regarding the bank lending effects of industry output growth, industry inflation, and monetary policy to be insensitive to the choice of aggregate and short-term lending. Motivated by these findings and to condense on space, this section presents and discusses the empirical evidence on the determinants of industry-specific short-term bank lending growth for the aggregate banking group. In a first step, section 6.2.1 reports the response of bank lending growth to industry output growth, industry inflation, and changes in the money market interest rate.

\footnotetext{
${ }^{48}$ Similar conclusions prevail when we compare the results for short- and long-term lending and short-, longterm, and aggregate lending. For reasons mentioned in section 5, we do not report the results for long-term lending.

${ }^{49}$ The ANOVA test statistics for estimations with bank capitalization, liquidity, and interbank assets and for aggregate lending are available on request.
} 
Section 6.2.2 then discusses the interaction terms between bank characteristics and monetary policy to draw conclusion as to the existence of credit channel effects of monetary policy through bank lending. Table 9 summarizes the coefficient estimates for the industry-specific bank lending functions.

The analysis of the interaction terms is subject to a shortcoming. As stated, the significance properties of the interaction terms preclude tests regarding the relative contribution of industries and banking groups as source of variation. Visual inspection of significant interaction terms points, however, to considerable differences in the sign and magnitude of the underlying credit channel effects across industries as well as banking groups. The differences are such that they in principle warrant a separate discussion of the coefficient estimates of all interaction terms. However, this is beyond scope given the large number of industry-specific bank lending models by bank characteristic, banking group, and loan maturity. ${ }^{50}$ We can only acknowledge that conclusions regarding the credit channel effects of monetary policy depend on the choice of model specification and stress the interaction terms for short-term bank lending growth for the aggregate banking group. Because the results regarding the credit channel effects of monetary policy vary with the choice of bank characteristic, we stress the evidence for bank asset size, capitalization, liquidity, and short-term interbank claims.

\subsubsection{The Bank Lending Effects of Loan Demand and Monetary Policy}

We report evidence for individual industries and for the grand total of industries. The evidence for the grand total of industries is our benchmark in the discussion of the industry-specific bank lending functions. Besides, when emphasizing the results for the grand total of industries, we can compare the present empirical findings with the evidence of earlier studies which do not adopt an industry-specific focus. In order to facilitate the readability of the results, we label industries by using abbreviations. For example, the finance and insurance industry is subsequently introduced as finance sector and the transport and communication sector is referred to as transport sector. Appendix A.1 provides details. Because the evidence in section 6.1 shows that the choice of bank characteristic does not affect the long-run sensitivity of bank lending with respect to industry output growth, industry inflation, or the money market interest rate, we provide a general discussion of the results regarding the industry-specific bank lending effects of bank credit demand and monetary policy.

Considering the response of bank lending growth to industry output growth, the entries in Table 9 illustrate that bank lending to the grand total of industries increases in response to higher output growth. The positive output response of lending to the grand total reflects the statistically significant and positive response of lending to growth in agriculture, construction, trade, services, and the food manufacturing sector. At least for the construction sector, the positive reaction of bank lending is influenced by the 1992-1995 re-unification construction boom period which induced heavy investment. Opposite relationships exist for the manufacturing sector and sub-sectors thereof which suggests that manufacturing firms demand less bank credit in response to output growth. ${ }^{51}$ Possible reasons are higher internal flows of fi-

\footnotetext{
${ }^{50}$ The results for aggregate lending and for the remaining banking groups are available on request.

${ }^{51}$ Also see Deutsche Bundesbank (1996) for a similar conclusion.
} 
nance which reduce external financing needs and/ or the absence of promising future economic prospects which yield disincentives for investment. Indeed, German manufacturing has experienced a continuous decline in terms of relative value added during the 1990s. ${ }^{52}$ Next to the manufacturing industry, we also find an inverse relationship between bank lending growth and output growth for the finance sector. In contrast to the manufacturing industry, the finance sector accounts for an increasingly larger share of aggregate value added. The decline in bank lending may, hence, reflect the effect of higher internal cash flows which reduce the need for bank finance.

As regards the response of bank lending growth to inflation, it is significant and positive for the grand total of industries. The positive reaction of bank lending to the grand total of industries is explained by the positive response of bank lending to all industries, but the transport and communication and machinery and transport equipment manufacturing sector.

-Insert Table 9 here-

Turning to the interest rate response of bank lending, the evidence confirms the view that higher interest rates cause lending to the grand total of industries to contract. The decline in bank lending reflects the negative effect of higher interest rates on bank reserves and precautionary lending on the part of banks in response to an increase in the risk of loan default. The evidence in Table 9 also illustrates that this response is a weighted average of the interest rate reaction of all industries. We find unanimous cross-industry differences in the nature of the interest rate response of bank lending. The negative interest rate response of lending to the grand total of industries reflects lower bank credit supply to the energy, manufacturing, and transport industry, with the interest rate effect being most pronounced for the first two sectors. The strength of the effect for the energy and manufacturing industry is attributed to the comparatively high capital intensity of production which is associated with a higher probability of loan losses (cf. Deutsche Bundesbank, 1996). For the manufacturing sector, the decline in lending reveals the negative interest rate effects of bank credit supply to the chemicals and coke, rubber and plastic, wood and paper, and textiles producing sector.

The negative interest rate effects are ameliorated by higher lending to the construction, trade, and finance industry and to producers of non-metallic mineral, machinery and transport equipment, and electrical and optical equipment goods. The positive interest rate response of lending to construction is not consistent with expectations. However, it can be attributed to the structural and cyclical characteristics of the construction sector. As regards the structural properties, the construction industry is characterized by a large share of small firms which predominantly obtain bank credit from local credit cooperatives and regional savings banks. ${ }^{53}$ Knowledge of local market conditions and local debtors reduces information asymmetries and fosters housebank relationships. Housebank relationships, in turn, facilitate the access to bank finance in general and in periods of high interest rates and low demand in particular. Considering cyclical factors, the positive interest rate response of bank lending reflects the

\footnotetext{
${ }^{52}$ The ratio of value added for manufacturing to value added for the grand total of industries declined from 0.26 in 1992 to 0.22 in 2002.

${ }^{53}$ Also see section 3.2 .
} 
demand-driven re-unification boom in construction. Even during the 1991-1992 period of high interest rates, demand for residential buildings and production plants was high and even continued to increase.

The positive interest rate response of bank lending to the finance industry can be explained in terms of financial stability considerations. A contraction in monetary policy lowers the net present value of financial assets and impedes on the ability of finance and insurance companies to generate profits on financial asset portfolios. When portfolio holders like firms or households view the return on their portfolio investment unsatisfactory, they will withdraw their funds from the finance and insurance sector. Besides return considerations, portfolio holders may also withdraw funds to accommodate the negative effect of higher interest rates on internal cash flows and, hence, liquidity. The drain of financial funds reduces the ability of finance and insurance companies to meet liquidity requirements. Due to self-fulfilling prophecies and herding behavior, this development may constitute a thread to the stability of the finance and insurance sector, with possible spillover effects to the whole financial system. In view of these relationships, the positive interest rate response of lending to the finance and insurance sector describes the effort of banks to ensure the stability of the financial system.

The entries in Table 9 point to pronounced industry differences in the magnitude of the bank lending effects of output growth, inflation, and interest rate changes. The largest response of bank lending to changes in monetary policy, industry inflation, and output growth is observed for the sub-sectors of the manufacturing industry. Indeed, bank lending to these sectors tends to be more responsive than bank lending to the manufacturing aggregate or to the grand total of industries. Next to the sub-sectors of the manufacturing industry, bank lending also responds comparatively strongly to output growth in the finance industry and to inflation in the construction and energy sector. The finance, construction, and energy industry and the sub-sectors of manufacturing have in common that the share of credit to these sectors is comparatively small (cf. Table 3). The evidence, hence, suggests that bank lending responds more to output growth and inflation in industries which only account for a small share of a bank's loan portfolio. This, in turn, suggests that banks primarily re-distribute credit between industries to which bank lending is relatively small and that the overall industry composition of a bank's loan portfolio is, accordingly, comparatively stable.

Overall, the evidence illustrates that the use of bank level data on aggregate lending only provides an imperfect view on the bank lending effects of credit demand and monetary policy. Our results indicate that the strength of aggregate bank lending effects clearly depends on the industry structure of bank credit portfolios. This finding is particularly interesting for the definition of monetary policy as it shows that the effectiveness of monetary policy depends on industry structure.

\subsubsection{Are there Bank Lending Effects of Monetary Policy?}

So far, the discussion has focused on the direct effects of monetary policy. This section presents the empirical results on the cross-bank differences in the interest rate response of industry-specific bank lending. The analysis emphasizes the results for the interaction between bank characteristics and monetary policy which capture the distributional effects of changes 
in the money market interest rate. As will be evident, conclusions as to the existence of cross-bank differences in the interest rate response of bank lending are sensitive to the choice of either bank asset size, capitalization, liquidity, and short-term interbank claims.

Existing studies question the usefulness of capitalization and liquidity as proxy variables of the bank lending effects of monetary policy. Gambacorta and Mistrulli (2004) argue that the capital-to-asset ratio is an inappropriate measure of bank capitalization. The reason is that bank capital does not illustrate the riskiness of a bank's portfolio. It therefore does not correctly describe the severity of information asymmetries which determines the ability of banks to obtain non-reservable funding. Kashyap and Stein (2000) contemplate that liquidity may provide a distorted view on the importance of bank balance sheet effects. This is because liquidity is also determined by cash which cannot be freely used by banks since it is subject to reserve requirements. ${ }^{54}$ Furthermore, Worms (2003) notes that bank lending reflects the liquidity preferences of banks, with more liquid banks lending less per se. If this holds, crossbank differences in the interest rate sensitivity of bank lending are not uniquely attributable to cross-bank differences in liquidity. We only mention these weaknesses associated with some bank characteristics, but do not control for them for two reasons. Firstly, the share of cash in total assets relative to other liquidity components is low and secondly, quarterly data on the riskiness of capital are not available in the present dataset. Even though capitalization and liquidity might be imperfect identifiers of bank credit supply effects of monetary policy, we report the results for these bank characteristics because we still assume that these variables influence the response of bank lending to interest rate changes.

Table 9 also contains the industry-specific bank lending effects of monetary policy associated with cross-bank differences in asset size, capitalization, liquidity, or short-term interbank claims. Conclusions regarding the bank lending effects of monetary policy transmission are sensitive to the choice of bank characteristic and vary with the choice of industry. The evidence lends strong support to the existence of bank size effects in monetary policy transmission. For the grand total of industries and for almost all sampled industries, monetary policy contraction causes bank lending of large banks to adjust less than bank credit of small banks. That is, large banks are better able to insulate their lending activities against interest rate induced changes in the availability of reservable and non-reservable funds of finance. Inconsistent with the credit channel theory, the interest rate response of bank lending to the finance industry is more pronounced for large than for small banks. This finding possibly reflects the importance of commercial banks as source of lending to the finance industry (Table 3) and the fact that commercial banks are on average larger in terms of asset size than savings banks and credit cooperatives (Table 1). Insignificant effects are recorded in estimations for the construction and transport sector and for the non-metallic goods and wood and paper products producing sector. In contrast to bank asset size, cross-bank heterogeneity in capitalization does not explain cross-bank differences in the interest rate sensitivity of bank credit to the grand total of industries and to most individual industries. The exception is lending to agriculture, finance, service, and manufacturing. Except for the agricultural sector, better capitalized banks adjust lending by less than poorly capitalized banks.

\footnotetext{
${ }^{54}$ We do not control for this claim given the low share of cash in total assets relative to other liquidity components and its time-invariability.
} 
Considering the broad and narrow measure of liquidity, the reaction of bank lending to the grand total of industries is driven by broad as well as narrow liquidity. Again, the bank lending effects of monetary policy differ across industries. Broad and/or narrow liquidity effects explain cross-bank differences in the interest rate response of lending to the agricultural, construction, trade, transport, textiles, food, machinery and transport equipment, and electrical and optical equipment producing sector. With the exception of lending to the machinery and transport equipment and electrical and optical equipment producing sector, liquidity helps to attenuate the interest rate response of bank lending, with the interest rate response of bank lending being larger for less liquid banks.

Except for agriculture and the machinery and transport equipment sector, significant liquidity effects only prevail for either the broad or narrow liquidity measure. For these sectors, the broad liquidity effect is driven by narrow liquidity rather than by short-term interbank claims. Indeed, the evidence shows that the significant short-term interbank effects are confined to very few industries: construction, trade, and transport. Because interbank claims are insignificant in explaining the interest rate response of credit supply to industries for which bank asset size possesses explanatory power, bank asset size appears to capture the bank lending effects of information asymmetries. That is, the evidence in the present study does not lend support to the finding of Worms (2003) according to which interbank claims dwarf the effects associated with bank asset size.

Comparing the magnitude of the distributional effects of monetary policy, differences prevail across bank characteristics. Indeed, cross-bank asymmetries in the interest rate response of bank lending are least pronounced for bank asset size and most pronounced for estimations with bank capitalization and short-term interbank claims. The evidence, hence, reveals that bank size is not the main determinant of cross-bank differences in the response to monetary policy changes. However, at least the relative importance of the capitalization effect should not be overemphasized because we define capitalization without correcting for bank risk. Next to these results, the entries in Table 9 also suggest that the strength of bank lending effects of monetary policy differs between industries. In contrast to direct monetary policy effects, the cross-industry differences appear to be unrelated to the relative weight of industries in a bank's credit portfolio.

Table 9 also reports the one-period lags of the bank characteristics. Even though the coefficients do not have an intrinsic meaning, they illustrate in combination with the direct interest rate effect whether bank characteristics or interest rate changes drive the significance of interaction terms. The evidence tends to be mixed. For the grand total of industries, the significance of the interaction term is attributable to the direct bank lending effect of monetary policy and to cross-bank differences in any of the bank characteristics. For the industry-specific bank lending functions, the distributional effects of monetary policy are determined by either monetary policy or bank characteristics, by both variables, or by none. For example, the significance of the interaction term on asset size and capitalization in the estimation for total manufacturing is driven by the the direct effect of monetary policy but not by bank characteristics. For the transport sector, the absence of credit channel effects in estimations with asset size seem to be driven by asset size given the evidence in favor of significant interest rate effects. Again, the evidence demonstrates that studies for the grand total of industries provide an incomplete view on the bank lending effects of monetary policy. Industry effects of 
monetary policy clearly exist and these determine the effectiveness of monetary policy for the industry aggregate.

\subsubsection{Comparison of the Results with Existing Studies}

The present results for the grand total of industries match those in Ehrmann et al. (2003) and Worms (2003) only partly. One possible source of divergence are differences in the definition of bank credit. While the earlier studies define bank credit for lending to households and the grand total of industries, we do not include household lending. ${ }^{55}$ Another source of heterogeneity concerns the outlier adjustment procedure. Ehrmann et al. (2003) and Worms (2003) identify outliers by assuming the normal distribution of banks, while we allow for skews in the distribution. The studies are, therefore, likely to define outliers along different lines which leads to the exclusion of different observations. The most striking difference, however, concerns the estimation methodology. Earlier studies estimate the dynamic panel model using the GMM estimator. We find this estimator to be inapplicable in the present study to the long sample period 1992-2002 as well as to the shorter sample period 1992-1998 as used by Worms (2003). We do not estimate the model for the short sample period with the fixed effects estimator because the finite sample bias would be stronger.

Despite these differences, our results are in line with those of Ehrmann et al. (2003) according to which bank lending grows in response to output growth and inflation and declines in the wake of monetary contraction. Our results only compare with those of Worms (2003) in terms of inflation and monetary policy. Furthermore, the present results are consistent with those in Ehrmann et al. (2003) according to which cross-bank differences in the interest rate sensitivity of aggregate bank credit cannot be attributed to differences in capitalization, but to differences in liquidity. However, the present study reports evidence which lends support to the existence of bank size effects in monetary policy transmission. In contrast to Worms (2003), the size effects are not driven by interbank claims since they also prevail in estimations which do not control for interbank claims.

\subsubsection{Synthesis}

Summarizing the results of the industry-specific bank lending functions, the evidence shows that bank lending growth is industry specific, being predominantly driven by cyclical changes in industry output growth and industry inflation and, hence, by industry-specific bank credit demand. The empirical findings show that the response of industry-specific bank lending to changes in monetary policy is comparatively small. Furthermore, they lend weak support to the transmission of monetary policy shocks through bank lending effects. If at all, crossbank differences in the response of bank lending to changes in monetary policy are primarily attributable to size and capitalization effects. We demonstrate that the determinants of

\footnotetext{
${ }^{55}$ Ehrmann et al. (2003) and Worms (2003) do not report evidence for short-term lending but for aggregate bank credit. Because our results for aggregate and short-term lending do not differ, we generalize our results when comparing them with earlier studies and do not make a distinction between short-term and aggregate lending.
} 
bank lending growth differ across industries. In fact, the discussion stresses the existence of significant cross-industry differences in the bank lending effects of industry output growth, industry inflation, and monetary policy. Bank lending growth, thus, depends on the relative importance of industries in a bank's loan portfolio.

\subsection{Robustness Tests}

In order to determine the robustness of the empirical findings, we modify the structure of the base specification (1) along several lines. To conserve on space, we only provide a verbal description of the corresponding evidence. ${ }^{56}$ One set of estimations eliminates output growth and inflation from the base model to test whether industry demand factors dwarf the bank lending effects of interest rate changes. The test is motivated by the evidence from the base model according to which bank lending growth is predominantly determined by industry output growth and industry inflation rather than by monetary policy. The results for the modified model confirm those for the base specification. We still find the direct interest rate effects on bank lending to be small, with the magnitude of the effects being in the range suggested by the base specification. The evidence in favor of credit channel effects of monetary policy through bank lending is still comparatively strong for asset size, but relatively weak for the remaining bank characteristics. Furthermore, the coefficient estimates from the augmented specification closely resemble those from the base model.

Another set of estimations re-estimates the base model with more than one bank characteristic. One specification interacts each bank characteristic individually with monetary policy (i.e., single interaction), while a second model interacts two bank characteristics with each other as well as with monetary policy (i.e., double interaction). ${ }^{57}$ We include more than one bank characteristic simultaneously for two reasons. One reason is the likely endogeneity between bank asset size and liquidity and bank capitalization and liquidity: large or better capitalized banks might be more liquid than small or poorly capitalized banks. The other reason refers to the possibility that models with only one bank characteristic report evidence which also captures the effects associated with other characteristics. This might be particularly true for interbank claims. Worms (2003) and Ehrmann et al. (2003) have shown that interbank claims attenuate the effects of asset size and dominate the liquidity or capitalization effects of monetary policy. Although the present study has shown that asset size explains the average interest rate response of banks in estimations which do not control for interbank claims, interbank claims may still capture part of the size effects. When including more than one bank characteristic, the models with single and double interactions yield evidence which largely confirms the findings of the base specification. Bank lending growth is predominantly determined by bank credit demand and not by monetary policy or the distributional effects of monetary policy. The strength of the underlying effects significantly differs between industries.

The model with single interactions jointly includes asset size and capitalization in addition to either broad or narrow liquidity, or interbank assets. The evidence from the augmented model suggests the independence of the effects associated with each bank characteristic. For example,

\footnotetext{
${ }^{56}$ The coefficient estimates for all robustness tests are available on request.

${ }^{57}$ See Ehrmann et al. (2003) and Worms (2003) for the structure of the model.
} 
the effects associated with bank capitalization are still comparatively strong, while bank size effects are relatively small. In fact, the strength of significant bank size, capitalization, liquidity, and interbank effects does not vary much between the base and augmented model. We therefore conclude that distributional effects of monetary policy reveal size and capitalization effects which are not driven by interbank claims or bank liquidity. Similarly, interbank assets do not influence the evidence on bank liquidity effects. For most bank lending functions, interbank assets are statistically insignificant and broad liquidity effects reflect the effects associated with narrow liquidity.

The model with double interaction terms tests whether cross-bank differences in the interest rate response of bank lending depend on the interdependence of effects associated with (i) interbank claims and either bank asset size, capitalization, or liquidity and (ii) liquidity and either bank asset size or capitalization. The hypothesis is that the effect of interbank claims or liquidity on the interest rate response of bank lending is smaller for large and better capitalized banks. Summarizing the results, we find the double interaction terms to be statistically insignificant in the bank lending functions of almost all industries. The only significant responses are recorded for estimations with interbank claims and either asset size, capitalization, or liquidity, but not in estimations with liquidity and either asset size or capitalization. When significant, the evidence tends to be inconsistent with expectations: interbank effects on bank lending are smaller for (i) small banks (machinery and transport equipment sector), (ii) poorly capitalized banks (electrical and optical equipment sector), (iii) less liquid banks (construction, services, wood and paper producing sector). Anticipated relationships prevail for the grand total of industries for which interbank effects of monetary policy on bank lending are smaller for large banks. In addition, interbank effects are smaller for liquid banks in estimations for the rubber and plastic and machinery and transport equipment sector.

As an alternative test we ask whether the results are sensitive to the way we define the explanatory variables of the base specification. The model in equation (1) includes industryspecific bank lending, output, and inflation without weighting each of these components by the corresponding bank-specific aggregate. In expressing loans in absolute terms, the present analysis follows Kishan and Opiela (2000), Gambacorta and Mistrulli (2004), Ehrmann et al. (2003), Worms (2003), Hülsewig, Mayer, and Wollmershäuser (2005), among others. In reality, banks operate portfolios, with lending to industry i being part of a diversification strategy. The relative importance of industries in a bank's portfolio, hence, differs. In order to control for differences in the importance of industries, we re-define the industry-specific variables relative to the aggregate. Doing so, we do not only control for differences in the relative importance of industries, but also for structural breaks which result from re-definitions in the composition of industries. Furthermore, we can also control for the effect of those mergers which do not appear as outliers. When using ratios, merger-driven jumps in lending are ameliorated or even eliminated. ${ }^{58}$ The results do not differ qualitatively from those of the base specification and confirm that bank lending growth is determined by bank credit demand rather than by monetary policy. Moreover, conclusions regarding the distributional effects of monetary policy on bank lending do not differ much between the base and augmented specification.

So far, the robustness checks involve structural changes of the base specification, using data

\footnotetext{
${ }^{58}$ See Appendix A.3 for the structure of the underlying model.
} 
for the sample period 1992:1-2002:4. This sample period captures years of exceptional circumstances as caused by German re-unification. Particular to this process is above average credit demand by all industries (cf. Deutsche Bundesbank, 1996). In order to assess the sensitivity of the results to re-unification effects, we also estimate the base specification for the period 1995:1-2002:4. For almost all industries, the results for the shorter time period do not differ qualitatively from those obtained for the longer time period. The only exception is the manufacturing industry. In contrast to the long sample period, bank lending to this sector is predicted to expand in response to industry inflation and to contract in reaction to higher interest rates. Conclusions regarding the existence of bank lending effects of monetary policy also change for bank asset size. In contrast to the long sample, the interest rate response of bank lending does no longer decrease with asset size, but increases. The relationships for output growth and the remaining bank characteristics do not change. The evidence for manufacturing is, hence, influenced by German re-unification. Visual inspection of the data shows that the results are driven by differences in the time-series pattern of inflation during 1992-1993 and 1994-2002. Manufacturing prices were constant during 1992-1993, while the share of short-term credit to manufacturing declined. Manufacturing prices only increased as of 1994.

Overall, conclusions as to the response of bank lending to changes in monetary policy and bank credit demand are robust to alternative model specifications. Regardless of the model, we find strong evidence that credit supply effects of monetary policy are small. Significant cross-industry differences still prevail which demonstrates that the sensitivity of a bank's credit portfolio to monetary policy changes or economic conditions clearly depends on the industry composition of a credit portfolio.

\section{Conclusion}

This paper has investigated the bank lending effects of bank credit demand and monetary policy for Germany for the sample period 1992:1-2002:4, using a unique data set with bank level data on bank balance sheet items and bank industry lending. In contrast to existing work on the credit channel effects of monetary policy, we explicitly focused on the industry effects of bank lending and estimated bank lending functions for eight industries at the one-digit industry level and for nine sub-sectors of the manufacturing industry at the two-digit industry level. The bank lending functions were defined for aggregate and short-term lending and for five individual banking groups. In line with existing studies, we used bank asset size, capitalization, liquidity, and short-term interbank claims as proxy variables of cross-bank differences in the severity of information asymmetries.

The evidence from dynamic fixed effects panel estimation shows that bank lending growth responds relatively strongly to industry output growth and inflation. Credit supply effects of monetary policy tend to be a less important determinant of bank lending growth. Our empirical findings lend strong support to the existence of industry effects of bank lending: industries are the most important source of variation in the bank lending effects of bank credit demand and monetary policy. Banking group effects are comparatively weak. This, in turn, suggests that the institutional setting of the German banking system is a relatively unimportant determinant 
of bank lending growth. The evidence lends mixed support to the credit channel theory according to which cross-bank differences in the interest rate response of bank lending can be explained with cross-bank heterogeneities in bank asset size, capitalization, liquidity, and short-term interbank claims. Again, the conclusions are very sensitive to the choice of industry and also depend on the choice of bank characteristic and banking group. When significant, the credit channel effects of monetary policy are much smaller than the bank credit demand effects. Overall, our results suggest that the industry composition of bank credit portfolios determines bank lending growth and - more important from an economic policy perspective the effectiveness of monetary policy.

We expect that the evidence in favor of industry effects of bank lending would also prevail in estimations which control for two shortcomings of the present analysis. One weakness concerns the assumption that positive and negative shocks to industry output growth, industry inflation, and monetary policy have a symmetric effect on bank lending growth. In reality, asymmetries are likely to prevail given that credit conditions worsen more in times of recessions than they improve in times of economic booms and that prices are sticky downwards but flexible upwards. Furthermore, we estimated a reduced-form model which does not control for the sensitivity of loan demand to monetary policy changes. That is, the interest rate sensitivity of bank lending reflects the interest rate response of bank credit supply as well as the interest rate response of bank credit demand. The interest rate sensitivity of loan demand, in turn, reflects the operation of alternative monetary policy transmission channels such as the interest rate or exchange rate channel.

Besides solving these issues, the present empirical results offer the following avenues for future research. Firstly, the evidence suggests that cross-industry differences in the response of bank lending to changes in bank credit demand and monetary policy cause the re-allocation of bank credit from one industry to another, ceteris paribus. ${ }^{59}$ Because industry performance also depends on the access to external finance, it would be particularly interesting from a policy perspective to determine the degree of sectoral credit shifts. If large, sectoral credit shifts will cause firms in some industries to be credit constraint even in absence of credit market imperfections. Secondly, the present paper has assumed that industry output growth and industry inflation affect bank lending unilaterally. However, the causal relationship is equally likely to run from bank lending growth to output growth and inflation. Panel causality tests would help to determine the nature and strength of the uni- or bi-directional relationships. Because conclusions are likely to differ between industries, the evidence from panel causality tests would provide more details on the determinants of the industry structure of bank credit portfolios.

This list of ideas is certainly not exhaustive. It becomes evident, however, that the present study should be viewed as starting point for future research on the industry effects of bank lending.

${ }^{59}$ The ceteris paribus condition refers to profitability and efficiency of industries. 


\section{References}

[1] Altunbaș, Y., O. Fazylov, and P. Molynex (2002). Evidence on the Bank Lending Channel in Europe. Journal of Banking and Finance, Vol. 26, pp. 2093-2110.

[2] Alvarez, J. and M. Arellano (2003). The Time Series and Cross-Section Asymptotics of Dynamic Panel Data Estimators. Econometrica, Vol. 71, pp. 1121-1159.

[3] Angeloni, I., A. Kashyap, and B. Mojon (2003). Monetary Policy Transmission in the Euro Area. Cambridge University Press.

[4] Arellano, M. (1987). Computing Robust Standard Errors for Within-Groups Estimators. Oxford Bulletin of Economics and Statistics, Vol. 49, pp. 431-434.

[5] Arellano, M. and S. Bond (1991). Some Tests of Specification for Panel Data: Monte Carlo Evidence and an Application to Employment Equations. The Review of Economic Studies, Vol. 58, pp. 277-297.

[6] Arellano, M. and S. Bond (1998). Dynamic Panel Data Estimation Using DPD98 for Gauss: A Guide for Users. unpublished manuscript.

[7] Arnold, I.J.M. and E.B. Vrugt (2004). Firm Size, Industry Mix, and the Regional Transmission of Monetary Policy in Germany. German Economic Review, Vol. 5 (1), pp. 35-59.

[8] Ashcraft, A.B. (2003). New Evidence on the Lending Channel. Federal Reserve Bank of New York. manuscript. Forthcoming in Journal of Money, Credit and Banking.

[9] Barran, F., V. Coudert, and B. Mojon (1997). The Transmission of Monetary Policy in the European Countries. In: S.C. Collignon (ed.): European Monetary Policy, London, pp. 81-111.

[10] Bernanke, B.S. and M. Gertler (1989). Agency Costs, Net Worth, and Business Fluctuations. American Economic Review, Vol. 79 (1), pp. 14-31.

[11] Blundell, R. and S. Bond (1998). Initial Conditions and Moment Restrictions in Dynamic Panel Data Models. Journal of Econometrics, Vol. 87, pp. 115-143.

[12] Blundell, R., S. Bond, and F. Windmeijer (2000). Estimation in Dynamic Panel Data Models: Improving on the Performance of the Standard GMM Estimators. The Institute for Fiscal Studies: WP No. 00/12. 
[13] Bondt, G.J. De (1998). Credit Channels in Europe: Bank-Level Panel Data Analyses. De Nederlandsche Bank: Research Memorandum WO\&E no. 543.

[14] Büschgen, H.E. (1998, 5th edition). Bankgeschäfte und Bankmanagement. Wiesbaden: Betriebswirtschaftlicher Verlag Dr. Th. Gabler GmbH, chapter 4B, pp. 796-806.

[15] Chatelain, J.-B., A. Generale, I. Hernando, U. von Kalckreuth, P. Vermeulen (2003). Firm Investment and Monetary Transmission in the Euro Area. In: I. Angeloni, A. Kashyap, and B. Mojon (eds.): Monetary Policy Transmission in the Euro Area. Cambridge University Press, chapter 7 .

[16] Corney, D. (2002). Intelligent Analysis of Small Data Sets for Food Design. University College London. Dissertation.

[17] Dale, S. and A.G. Haldane (1995). Interest Rates and the Channels of Monetary Transmission: Some Sectoral Estimates. European Economic Review, Vol. 39 (9), pp. 1611-1626.

[18] Dedola, L. and F. Lippi (2005). The Monetary Transmission Mechanism: Evidence from the Industries of Five OECD Countries. European Economic Review, Vol. 49 (6), pp. 1543-1569.

[19] Deutsche Bundesbank (1996). Kreditentwicklung nach Kreditnehmern und Bankengruppen. Deutsche Bundesbank: Monthly Report, Vol. 48 (10), pp. 49-63.

[20] Deutsche Bundesbank (1998a). Trends in the Banking Sector and the Market Position of the Individual Categories of Banks since the Beginning of the Nineties. Deutsche Bundesbank: Monthly Report, Vol. 50 (3), pp. 33-64.

[21] Deutsche Bundesbank (1998b). Methodische Grundlagen der Unternehmensbilanzstatistik der Deutschen Bundesbank. Deutsche Bundesbank: Monthly Report, Vol. 50 (10), pp. 51-67.

[22] Deutsche Bundesbank (2000). The Relationship between Bank Lending and the Bond Market in Germany. Deutsche Bundesbank: Monthly Report, Vol. 52 (1), pp. 33-47.

[23] Deutsche Bundesbank (2001). Bank Balance Sheets, Bank Competition, and Monetary Policy Transmission. Deutsche Bundesbank: Monthly Report, Vol. 53 (9), pp. 51-70.

[24] Deutsche Bundesbank (2002a). The Pass-Through from Market Interest Rates to Bank Lending Rates in Germany. Deutsche Bundesbank: Monthly Report, Vol. 54 (3), pp. 49-62. 
[25] Deutsche Bundesbank (2002b). Monetary Policy and Investment Behavior - An Empirical Study. Deutsche Bundesbank: Monthly Report, Vol. 54 (7), pp. 41-54.

[26] Deutsche Bundesbank (2002c). The Development of Bank Lending to the Private Sector. Deutsche Bundesbank: Monthly Report, Vol. 54 (10), pp. 31-47.

[27] Ehrmann, M., L. Gambacorta, J. Martínez-Pagés, P. Sevestre, and A. Worms (2003). Financial Systems and the Role of Banks in Monetary Policy Transmission in the Euro Area. In: I. Angeloni, A. Kashyap, and B. Mojon (eds.): Monetary Policy Transmission in the Euro Area. Cambridge University Press.

[28] Ehrmann, M. and A. Worms (2004). Bank Networks and Monetary Policy Transmission. Journal of the European Economic Association, Vol. 2 (6), pp. 1148-1171.

[29] Elsas, R. and J.P. Krahnen (2004). Universal Banks and Relationships with Firms. In: J.P. Krahnen and R.H. Schmidt (eds.). The German Financial System. Oxford: Oxford University Press, pp. 197-232.

[30] Elsas, R. and J.P. Krahnen (1998). Is Relationship Lending Special? Evidence from Credit-File Data in Germany. Journal of Banking and Finance, Vol. 22, pp. 1283-1316.

[31] European Commission (2003). SMEs and Access to Finance. Observatory of European SMEs No. 2.

[32] Favero, C.A., F. Giavazzi, and L. Flabbi (1999). The Transmission Mechanism of Monetary Policy in Europe: Evidence from Bank's Balance Sheets. Cambridge, Mass.: NBER WP 7231.

[33] Fischer, K.-H. (2001). Banken und unvollkommener Wettbewerb - Empirische Beiträge zu einer Industrieökonomik der Finanzmärkte. Goethe University Fankfurt/ Main: Ph.D. Dissertation.

[34] Gambacorta, L. and P.E. Mistrulli (2004). Does Bank Capital Affect Lending Behavior? Journal of Financial Intermediation, Vol. 13, pp. 435-457.

[35] Garretsen, H. and J. Swank (1998). The Transmission of Interest Rate Changes and the Role of Bank Balance Sheets: A VAR Analysis for the Netherlands. Journal of Macroeconomics, Vol. 20 (2), pp. 325-339.

[36] Gertler, M. and S. Gilchrist (1993). The Cyclical Behavior of Short-Term Business Lending. European Economic Review, Vol. 37, pp. 623-631. 
[37] Guender, A. and M. Moersch (1997). On the Existence of a Credit Channel of Monetary Policy in Germany. Kredit und Kapital, Vol. 30, pp. 173-185.

[38] Haan, J. De (2003). The Impact of Monetary Policy on Bank Lending in the Netherlands. In: I. Angeloni, A. Kashyap, and B. Mojon (eds.): Monetary Policy Transmission in the Euro Area. Cambridge University Press, Chapter 20.

[39] Hackethal, A. (2004). German Banks and Banking Structure. In: J.P. Krahnen and R.H. Schmidt (eds.). The German Financial System. Oxford: Oxford University Press, pp. 69-105.

[40] Harhoff, D. and T. Körting (1998). Lending Relationships in Germany - Empirical Evidence from Survey Data. Journal of Banking and Finance, Vol. 22, pp. 1317-1353.

[41] Hayo, B. and B. Uhlenbrock (2000). Industry Effects of Monetary Policy in Germany. In: J. von Hagen and C. Waller (ed.). Regional Aspects of Monetary Policy in Europe. Dordrecht: Kluwer Academic Publishers, pp. 127-158.

[42] Henrekson, M. and D. Johansson (1999). Institutional Effects on the Evolution of the Size Distribution of Firms. Small Business Economics, Vol. 12, pp. 11-23.

[43] Holtemöller, O. (2003). Further VAR Evidence for the Effectiveness of a Credit Channel in Germany. Applied Economics Quarterly, Vol. 49 (4), pp. 359-381.

[44] Hülsewig, O., P. Winker, and A. Worms (2004). Bank Lending in the Transmission of Monetary Policy: A VECM Analysis for Germany. Jahrbücher für Nationalökonomie und Statistik, Vol. 224 (5), pp. 511-529.

[45] Hülsewig, O., E. Mayer, and T. Wollmershäuser (2005). Bank Loan Supply and Monetary Policy Transmission in Germany: An Assessment Based on Matching Impulse Responses. Munich: CESifo Working Paper No. 1380.

[46] Jung, H. (2005). A Test for Autocorrelation in Dynamic Panel Data Models. Hitotsubashi University: Hi-Stat Discussion Paper Series No. 77.

[47] Kakes, J., J.-E. Sturm, and P. Maier (2001). Monetary Transmission and Bank Lending in Germany. Kredit und Kapital (4).

[48] Kakes, J. and J.-E. Sturm (2002). Monetary Policy and Bank Lending: Evidence from German Banking Groups. Journal of Banking and Finance, Vol. 26, pp. 2077-2092. 
[49] Kalckreuth, U. von (2001). Monetary Transmission in Germany: New Perspectives on Financial Constraints and Investment Spending. Deutsche Bundesbank: Discussion Paper No. $19 / 01$.

[50] Kashyap, A.K. and J.C. Stein (1995). The Impact of Monetary Policy on Bank Balance Sheets. Carnegie-Rochester Conference Series on Public Policy, Vol. 42, pp. 151-195.

[51] Kashyap, A.K. and J.C. Stein (2000). What Do a Million Observations on Banks Say about the Transmission of Monetary Policy? American Economic Review, Vol. 90, pp. 407-428.

[52] Kishan, R.P. and T.P. Opiela (2000). Bank Size, Bank Capital, and the Bank Lending Channel. Journal of Money, Credit, and Banking, Vol. 32 (1), pp. 121-141.

[53] Kiviet, J. (1995). On Bias, Inconsistency, and Efficiency of Some Estimators in Dynamic Panel Data Models. Journal of Econometrics, Vol. 68 (1), pp. 63-78.

[54] Küppers, M. (2001). Curtailing the Black Box: German Banking Groups in the Transmission of Monetary Policy. European Economic Review, Vol. 45, pp. 1907-1930 .

[55] Kuttner, K. and P.C. Mosser (2002). The Monetary Transmission Mechanism: Some Answers and Further Questions. Federal Reserve Bank of New York: Economic Policy Review, Vol. 8 (1), pp. 15-26.

[56] Loveman, G. and W. Sengenberger (1991). The Reemergence of Small-Scale Production: An International Comparison. Small Business Economics, Vol. 3 (1), pp. 1-37.

[57] Mojon, B. (2000). Financial Structure and the Interest Rate Channel of ECB Monetary Policy. European Central Bank: Working Paper Series No. 40.

[58] Mojon, B., F. Smets, and P. Vermeulen (2002). Investment and Monetary Policy in the Euro Area. Journal of Banking and Finance, Vol. 26 (11), pp. 2111-2129.

[59] Nickell, S. (1981). Biases in Dynamic Models with Fixed Effects. Econometrica, Vol. 49, pp. 1417-1426.

[60] Peek, J. and E. Rosengren (1995). Bank Lending and the Transmission of Monetary Policy. In: J. Peek and E. Rosengren (eds.): Is Bank Lending Important for the Transmission of Monetary Policy? Federal Reserve Bank of Boston Conference Series, Vol. 39, pp. 47-68.

[61] Peersman, G. and F. Smets (2005). The Industry Effects of Monetary Policy in the Euro Area. Economic Journal, Vol. 115 (503), pp. 319-342. 
[62] Siegfried, N.A. (2000). Microeconometric Evidence for a German Credit Channel. Hamburg University: Quantitative Macroeconomics Working Paper Series No. 1/2000.

[63] Trautwein, H.-M. (2000). The Credit View, Old and New. Journal of Economic Surveys, Vol. 14 (2), pp. 155-189.

[64] Worms, A. (2003). Interbank Relationships and the Credit Channel in Germany. Empirica, Vol. 30 (2), pp. 179-198. 


\section{Appendix A}

\section{Data Sources and Descriptions}

\section{A.1 Data Description}

The following table lists the industries for which data on economic activity, prices, and industry characteristics are compiled. The second column labels the industry as it will be abbreviated throughout the paper.

Industry

Abbreviation

Source

Grand total

$\begin{array}{ll} & \mathrm{NC} \\ \text { Energy } & \mathrm{NC} \\ & \mathrm{NC} \\ \text { Food } & \mathrm{NC} \\ \text { Textiles } & \mathrm{NC} \\ \text { Wood } & \mathrm{NC} \\ \text { Paper } & \mathrm{NC} \\ \text { Coke } & \mathrm{NC} \\ \text { Chemicals } & \mathrm{NC} \\ \text { Rubber and plastic } & \mathrm{NC} \\ \text { Non-metallic mineral } & \mathrm{NC} \\ \text { Metals } & \mathrm{NC} \\ \text { Machinery } & \mathrm{NC} \\ \text { Electrical equipment } & \mathrm{NC} \\ \text { Transport equipment } & \mathrm{NC} \\ \text { Construction } & \mathrm{NC} \\ \text { Agriculture } & \mathrm{GSO} \\ \text { Service } & \mathrm{GSO} \\ \text { Trade } & \mathrm{GSO} \\ \text { Transport } & \mathrm{GSO} \\ \text { Finance } & \mathrm{GSO}\end{array}$

Finance and insurance

Finance

GSO

The empirical analysis does not include all industries individually, but also combinations of sectors. An aggregation of sectors is necessitated by the definition of industry sectors in the 
Bundesbank borrower statistics. The following industries are treated as a single unit: wood and paper; coke and chemicals; machinery and transport equipment.

With few exceptions, monthly data on the industry production index and industry price index, and annual data on the number of enterprises with 1 to 19 employees are compiled from the New Cronos database of Eurostat (NC). The monthly data are converted into quarterly data. Industry data on agriculture, services, wholesale and retail trade, finance and insurance, and transport and communication are obtained from the German statistical office (GSO). Information on value added, employment, gross capital stock, imports, exports, and operating surplus are from the OECD's STAN database for Industrial Analysis. The data are available at an annual frequency.

Data on bank characteristics are compiled from the Bundesbank's monthly bank balance sheet statistics. The following variables are used:

- Total assets

- Bank capital

- Liquidity

Bank capital includes subscribed capital, reserves, capital represented by participation rights and the fund for general banking risk. Liquidity is defined as the sum of cash; balances with the central banks; treasury bills, treasury certificates, and similar debt instruments issued by public authorities (eligible for refinancing); debt securities; shares and other variable-yield securities; claims on credit institutions with an agreed maturity or redeemable at notice of one year or less (short-term interbank claims). ${ }^{60}$

Data on bank-specific lending to eight main industries and nine sub-sectors of the manufacturing industry are compiled from the quarterly borrower statistics of the Deutsche Bundesbank.

\section{A.2 Variable Description}

The vector of bank characteristics $X_{b}$ in equation (1) includes variables related to bank efficiency and profitability: total assets (TA), liquidity $(A)$, and bank capital $(K)$. In line with existing studies (cf. Ehrmann et al., 2003; Gambacorta and Mistrulli, 2004; Worms, 2003), the level of bank-specific capital $\mathrm{Cap}_{\mathrm{b}}$, broad liquidity Bliq $\mathrm{b}_{\mathrm{b}}$, narrow liquidity $\mathrm{Nliq}_{\mathrm{b}}$, and short-

\footnotetext{
${ }^{60}$ The determinants of liquidity are ranked according to liquidity. From the top to the bottom, liquidity declines. See Büschgen (1998), chapter 4.B for details.
} 
term interbank claims $\mathrm{Ibk}_{\mathrm{b}}$ is normalized with respect to the average across all banks and time according to

$$
\begin{aligned}
& \mathrm{Cap}_{\mathrm{bt}}=\frac{\mathrm{K}_{\mathrm{bt}}}{\mathrm{TA}_{\mathrm{bt}}}-\frac{1}{\mathrm{~T}} \sum_{\mathrm{t}=1}^{\mathrm{T}}\left(\frac{1}{\mathrm{~N}_{\mathrm{b}}} \sum_{\mathrm{b}=1}^{\mathrm{N}_{\mathrm{b}}} \frac{\mathrm{K}_{\mathrm{bt}}}{\mathrm{TA}_{\mathrm{bt}}}\right), \\
& \mathrm{Bliq}_{\mathrm{bt}}=\frac{\mathrm{A}_{\mathrm{bt}}}{\mathrm{TA} A_{\mathrm{bt}}}-\frac{1}{\mathrm{~T}} \sum_{\mathrm{t}=1}^{\mathrm{T}}\left(\frac{1}{\mathrm{~N}_{\mathrm{b}}} \sum_{\mathrm{b}=1}^{\mathrm{N}_{\mathrm{b}}} \frac{\mathrm{A}_{\mathrm{bt}}}{\mathrm{TA} A_{\mathrm{bt}}}\right) \\
& N \operatorname{Niq}_{b t}=\frac{A_{b t}-\mathrm{lbk}_{\mathrm{bt}}}{\mathrm{TA}_{\mathrm{bt}}}-\frac{1}{\mathrm{~T}} \sum_{\mathrm{t}=1}^{\mathrm{T}}\left(\frac{1}{\mathrm{~N}_{\mathrm{b}}} \sum_{\mathrm{b}=1}^{\mathrm{N}_{\mathrm{b}}} \frac{\mathrm{A}_{\mathrm{bt}}-\mathrm{lb} k_{\mathrm{bt}}}{\mathrm{TA} A_{\mathrm{bt}}}\right), \\
& \mathrm{lbk}_{\mathrm{bt}}=\frac{\mathrm{lbk}_{\mathrm{bt}}}{\mathrm{TA} A_{\mathrm{bt}}}-\frac{1}{\mathrm{~T}} \sum_{\mathrm{t}=1}^{\mathrm{T}}\left(\frac{1}{\mathrm{~N}_{\mathrm{b}}} \sum_{\mathrm{b}=1}^{\mathrm{N}_{\mathrm{b}}} \frac{\mathrm{lbk_{bt }}}{\mathrm{TA} A_{\mathrm{bt}}}\right),
\end{aligned}
$$

respectively. The bank characteristics are expressed in terms of total assets to de-trend these series. To this end, we assume that bank capitalization, liquidity, and interbank claims follow similar trends as asset size. Total assets (TA) are also normalized with respect to the mean across all banks, but de-trending requires the normalization for each single data point. This yields the following measure of bank asset size

$$
\text { Size }_{b t}=\log T A_{b t}-\frac{1}{N_{b}} \sum_{b=1}^{N_{b}} \log T A_{b t} .
$$

Normalization with respect to the average across all banks means that the indicator variables Size, Cap, Bliq, Nliq, and Ibk sum to zero over all observations. Because of this property, the interaction terms in equation (1) are on average equal to zero. In addition, the coefficient estimate $\gamma_{1 j}$ directly reflects the average effect of monetary policy on bank credit growth.

\section{A.3 Alternative Model Specification}

In order to control for the relative importance of industries in a bank's portfolio relative to the aggregate, the base specification in equation (1) is rewritten as 


$$
\begin{aligned}
\Delta \frac{\mathrm{L}_{\mathrm{bi}, \mathrm{t}}}{\mathrm{L}_{\mathrm{b}, \mathrm{t}}}= & \alpha_{\mathrm{b}}+\sum_{\mathrm{j}=1}^{\mathrm{p}} \beta_{\mathrm{ij}} \Delta \frac{\mathrm{L}_{\mathrm{bi}, \mathrm{t}-\mathrm{j}}}{\mathrm{L}_{\mathrm{b}, \mathrm{t}-\mathrm{j}}}+\sum_{\mathrm{j}=1}^{\mathrm{p}} \gamma_{1 j} \Delta \mathrm{r}_{\mathrm{m}, \mathrm{t}-\mathrm{j}}+\sum_{\mathrm{j}=1}^{\mathrm{p}} \gamma_{2, \mathrm{ij}} \Delta \frac{\mathrm{IP} \mathrm{P}_{\mathrm{i}, \mathrm{t}-\mathrm{j}}}{\mathrm{IP}_{\mathrm{t}-\mathrm{j}}}+\sum_{\mathrm{j}=1}^{\mathrm{p}} \gamma_{3, \mathrm{ij}} \Delta \frac{\text { Price }_{\mathrm{i}, \mathrm{t}-\mathrm{j}}}{\text { Price }_{\mathrm{t}-\mathrm{j}}}+ \\
& \gamma_{4} \mathrm{X}_{\mathrm{b}, \mathrm{t}-1}+\sum_{\mathrm{j}=1}^{\mathrm{p}} \gamma_{5} \mathrm{X}_{\mathrm{b}, \mathrm{t}-1} \Delta \mathrm{r}_{\mathrm{m}, \mathrm{t}-\mathrm{j}}+\epsilon_{\mathrm{bi,t}}
\end{aligned}
$$




\section{Appendix B}

\section{Tables}


Table 1: Summary Statistics of Bank Balance Sheet Variables, 1992-2002

N $\quad$ Mean Stdev Skew. Kurtosis

\section{Assets}

Commercial BG

- Big B.

- Regional, Private B.

Savings BG

- Land B.

- Savings B.

Cooperative BG

- Central Institutes

- Cooperative B.

Aggregate BG

N Mean Stdev Skew. Kurtosis

\section{Capitalization}

Commercial BG

- Big B.

- Regional, Private B.

Savings BG

- Land B.

- Savings B.

Cooperative BG

- Central Institutes

- Cooperative B.

Aggregate BG

$\begin{array}{lllll}144 & 19.98 & 0.44 & -0.29 & 1.90 \\ 6475 & 14.25 & 1.80 & 0.28 & 3.02 \\ & & & & \\ 571 & 18.74 & 1.02 & -1.84 & 10.11 \\ 25200 & 14.69 & 0.94 & 0.06 & 3.02 \\ & & & & \\ 152 & 18.36 & 0.77 & 0.73 & 2.42 \\ 96785 & 12.63 & 1.06 & 0.41 & 3.32 \\ 128604 & 13.12 & 1.40 & 0.61 & 3.58\end{array}$

\section{Liquidity}

Commercial BG

- Big B.

- Regional, Private B.

Savings BG

- Land B.

- Savings B.

Cooperative BG

- Central Institutes

- Cooperative B.

Aggregate BG

4. Short Interbank Claims Commercial BG

- Big B.

- Regional, Private B.

Savings BG

- Land B.

- Savings B.

Cooperative BG

- Central Institutes

- Cooperative B.

Aggregate BG

$\begin{array}{lllll}148 & 0.06 & 0.01 & 0.28 & 1.81 \\ 6770 & 0.08 & 0.04 & 1.43 & 5.05 \\ & & & & \\ 592 & 0.03 & 0.01 & 0.55 & 2.88 \\ 25800 & 0.04 & 0.01 & 0.37 & 3.12 \\ & & & & \\ 156 & 0.03 & 0.01 & 0.50 & 3.66 \\ 101360 & 0.05 & 0.01 & 0.71 & 4.09 \\ 133673 & 0.05 & 0.02 & 4.46 & 40.27\end{array}$

$\begin{array}{lllll}148 & 0.20 & 0.04 & 0.51 & 2.53 \\ 7433 & 0.29 & 0.18 & 0.84 & 3.70 \\ & & & & \\ 592 & 0.23 & 0.07 & 0.22 & 2.27 \\ 26552 & 0.32 & 0.10 & 0.84 & 3.78 \\ & & & & \\ 156 & 0.36 & 0.08 & 0.41 & 2.52 \\ 101831 & 0.28 & 0.10 & 0.72 & 3.76 \\ 135829 & 0.29 & 0.11 & 0.79 & 4.54\end{array}$

-continued on next page-

$\begin{array}{lllll}148 & 0.03 & 0.01 & 0.26 & 2.43 \\ 6817 & 0.06 & 0.07 & 1.41 & 5.06 \\ & & & & \\ 592 & 0.06 & 0.05 & 1.75 & 7.42 \\ 25851 & 0.03 & 0.04 & 1.77 & 7.02 \\ & & & & \\ 156 & 0.12 & 0.08 & 0.55 & 2.59 \\ 101183 & 0.05 & 0.05 & 1.72 & 7.02 \\ 133158 & 0.05 & 0.05 & 1.66 & 6.40\end{array}$


N Mean Stdev Skew. Kurtosis

\section{Lending to Non-Banks}

Commercial BG

- Big B.

- Regional, Private B.

Savings BG

- Land B.

- Savings B.

Cooperative BG

- Central Institutes

- Cooperative B.

Aggregate BG

\section{Total Credit to Industries}

Commercial BG

- Big B.

- Regional, Private B.

Savings BG

- Land B.

- Savings B.

Cooperative BG

- Central Institutes

- Cooperative B.

Aggregate BG

7. Short-Term Credit to Industries

Commercial BG

- Big B.

- Regional, Private B.

Savings BG

- Land B.

- Savings B.

Cooperative BG

- Central Institutes

- Cooperative B.

Aggregate BG

$\begin{array}{rllll}131 & 0.50 & 0.11 & -0.95 & 3.40 \\ 3395 & 0.55 & 0.20 & -0.34 & 2.74 \\ & & & & \\ 568 & 0.40 & 0.09 & -0.44 & 3.65 \\ 20386 & 0.61 & 0.10 & -1.34 & 5.24 \\ & & & & \\ 156 & 0.17 & 0.07 & -0.20 & 1.74 \\ 91683 & 0.60 & 0.11 & -0.70 & 3.40 \\ 115595 & 0.60 & 0.11 & -0.85 & 4.09\end{array}$

$\begin{array}{rrrrr}131 & 0.58 & 0.08 & -0.68 & 3.12 \\ 3043 & 0.54 & 0.25 & -0.56 & 2.19 \\ & & & & \\ 568 & 0.45 & 0.09 & -0.19 & 2.92 \\ 20350 & 0.45 & 0.08 & -0.28 & 3.42 \\ & & & & \\ 156 & 0.65 & 0.16 & -0.65 & 2.21 \\ 91309 & 0.46 & 0.13 & -0.28 & 4.07 \\ 114833 & 0.46 & 0.12 & -0.19 & 4.44\end{array}$

\begin{tabular}{rrrrr}
131 & 0.40 & 0.10 & -1.69 & 5.14 \\
3036 & 0.54 & 0.26 & 0.13 & 2.02 \\
& & & & \\
568 & 0.16 & 0.09 & 5.40 & 48.64 \\
20342 & 0.22 & 0.06 & 1.14 & 8.20 \\
& & & & \\
156 & 0.33 & 0.09 & 0.65 & 4.93 \\
91031 & 0.26 & 0.08 & 0.63 & 5.22 \\
114540 & 0.26 & 0.10 & 2.53 & 16.53 \\
\hline
\end{tabular}

Notes: Assets (panel 1) are expressed in logarithm. The balance sheet positions capitalization (panel 2), liquidity (panel 3), interbank claims (panel 4), and total lending to non-banks (panel 5) are expressed as share of total assets. Lending to non-banks includes lending to domestic businesses, private households, government, and foreign non-banks. Lending to industries combines bank credit to businesses and self-employed. Aggregate lending to industries (panel 6) is expressed as share of total non-bank lending. Short-term lending to industries (panel 7) is expressed as share of aggregate lending to industries. Bank credit to industries reflects lending to firms and self-employed. The descriptive statistics for savings banks are for public rather than for private savings banks. The aggregate banking group only consists of the primary institutions of the commercial, savings, and cooperative banking group. The data are from the monthly bank balance sheet statistics of the Deutsche Bundesbank. 
Table 2: One-Way ANOVA of Bank Balance Sheet Variables, 1992-2002

Panel A Main Banking Groups

\begin{tabular}{llrrrrr}
\hline \hline \multirow{2}{*}{ Variable } & Source of Variation & SS & DF & MS & F-Value \\
& & & & & & \\
\hline \multirow{3}{*}{ Assets } & Between Groups & 97209 & 2 & 48604 & 39429 & $*$ \\
& Within Groups & 158911 & 128913 & 1.23 & & \\
Capitalization & Between Groups & 7.10 & 2 & 3.53 & 19356 & $*$ \\
& Within Groups & 24.46 & 133982 & 0.000 & & \\
Liquidity & Between Groups & 29.96 & 2 & 14.98 & 1350 & $*$ \\
& Within Groups & 1510 & 136138 & 0.011 & & \\
Short-Term Interbank Claims & Between Groups & 6.25 & 2 & 3.12 & 1290 & $*$ \\
& Within Groups & 323 & 133467 & 0.002 & & \\
Lending to Non-Banks & Between Groups & 12.15 & 2 & 6.08 & 491 & $*$ \\
& Within Groups & 1431 & 115592 & 0.012 & & \\
Total Credit to Industries & Between Groups & 20.52 & 2 & 10.26 & 676 & $*$ \\
& Within Groups & 1744 & 114830 & 0.015 & & \\
Short-Term Credit to Industries & Between Groups & 99.81 & 2 & 49.90 & 13897 & $*$ \\
& Within Groups & 411 & 114537 & 0.004 & & \\
\hline \hline
\end{tabular}

Notes: Assets are expressed in logarithm. Total and short-term credit to industries are expressed as share of non-bank lending. The remaining variables are expressed in terms of total assets. The main banking groups are the commercial banking group and the primary institutions of the savings and credit cooperative banking sector. ${ }^{*}$ denotes the statistical significance at the one percent level, respectively. The data are from the monthly bank balance sheet statistics of the Deutsche Bundesbank. 
Panel B Cooperative Banking Group

\begin{tabular}{llrrrrr}
\hline \hline \multirow{2}{*}{ Variable } & Source of Variation & SS & DF & MS & F-Value \\
& & & & & & \\
\hline \multirow{3}{*}{ Assets } & Between Groups & 48626 & 5 & 9725 & 15512 & $*$ \\
& Within Groups & 60673 & 96775 & 0.627 & & \\
Capitalization & Between Groups & 0.24 & 5 & 0.047 & 493 & $*$ \\
& Within Groups & 9.66 & 100942 & 0.000 & & \\
Liquidity & Between Groups & 34.20 & 5 & 6.84 & 713 & $*$ \\
& Within Groups & 975 & 101683 & 0.010 & & \\
Short-Term Interbank Claims & Between Groups & 4.06 & 5 & 0.811 & 320 & $*$ \\
& Within Groups & 254 & 100329 & 0.003 & & \\
Lending to Non-Banks & Between Groups & 31.35 & 5 & 6.27 & 546 & $*$ \\
& Within Groups & 1053 & 91677 & 0.011 & & \\
Total Credit to Industries & Between Groups & 416 & 5 & 83.30 & 7491 & $*$ \\
& Within Groups & 1015 & 91303 & 0.011 & & \\
Short-Term Credit to Industries & Between Groups & 42.39 & 5 & 8.28 & 3457 & $*$ \\
& Within Groups & 218 & 91025 & 0.002 & & \\
\hline
\end{tabular}

Notes: The cooperative banking group comprises commercial and rural credit cooperatives, Raiffeisen banks, Sparda and PSD banks, and civil servants banks. Also see the notes to panel $A$. 
Table 3: Summary Statistics of Bank Lending to Industries, 1992-2002

\begin{tabular}{|c|c|c|c|c|c|c|c|c|c|c|}
\hline \multirow[b]{2}{*}{ Lending to: } & \multicolumn{5}{|c|}{ Aggregate Lending } & \multicolumn{5}{|c|}{ Short-Term Lending } \\
\hline & $\mathrm{N}$ & Mean & Stdev & Skew. & Kurtosis & $\mathrm{N}$ & Mean & Stdev & Skew. & Kurtosis \\
\hline \multicolumn{11}{|l|}{ Agr } \\
\hline Commercial BG & 942 & 0.05 & 0.09 & 3.75 & 27.02 & 3060 & 0.04 & 0.10 & 6.35 & 48.10 \\
\hline Savings BG & 21657 & 0.04 & 0.04 & 3.34 & 19.57 & 24292 & 0.04 & 0.04 & 3.06 & 17.56 \\
\hline Cooperative BG & 85636 & 0.17 & 0.15 & 1.36 & 4.93 & 93216 & 0.13 & 0.13 & 1.88 & 7.59 \\
\hline \multicolumn{11}{|l|}{ Enr } \\
\hline Commercial BG & 1141 & 0.04 & 0.08 & 6.38 & 56.31 & 2564 & 0.04 & 0.12 & 6.06 & 47.45 \\
\hline Savings BG & 7922 & 0.02 & 0.03 & 2.94 & 16.14 & 17606 & 0.01 & 0.02 & 7.37 & 95.52 \\
\hline Cooperative BG & 8987 & 0.02 & 0.02 & 3.36 & 20.44 & 33024 & 0.01 & 0.03 & 9.52 & 191.63 \\
\hline \multicolumn{11}{|l|}{ Con } \\
\hline Commercial BG & 1648 & 0.06 & 0.04 & 1.92 & 10.27 & 3916 & 0.06 & 0.06 & 2.38 & 14.02 \\
\hline Savings BG & 23390 & 0.11 & 0.04 & 0.95 & 4.76 & 25030 & 0.15 & 0.06 & 1.00 & 4.84 \\
\hline Cooperative BG & 86792 & 0.13 & 0.06 & 1.72 & 12.13 & 94296 & 0.17 & 0.10 & 1.35 & 6.64 \\
\hline \multicolumn{11}{|l|}{ Trd } \\
\hline Commercial BG & 2754 & 0.24 & 0.19 & 2.10 & 7.53 & 5308 & 0.33 & 0.27 & 1.23 & 3.69 \\
\hline Savings BG & 23406 & 0.21 & 0.05 & 0.56 & 5.19 & 24939 & 0.25 & 0.08 & 0.54 & 4.23 \\
\hline Cooperative BG & 88148 & 0.19 & 0.08 & 1.18 & 11.15 & 94422 & 0.22 & 0.11 & 0.98 & 7.19 \\
\hline \multicolumn{11}{|l|}{ Trt } \\
\hline Commercial BG & 1320 & 0.05 & 0.08 & 4.25 & 23.75 & 3960 & 0.03 & 0.05 & 4.13 & 28.94 \\
\hline Savings BG & 22768 & 0.04 & 0.02 & 3.13 & 23.98 & 24720 & 0.03 & 0.03 & 4.06 & 37.58 \\
\hline Cooperative BG & 67973 & 0.04 & 0.04 & 3.57 & 38.74 & 83667 & 0.03 & 0.06 & 63.72 & 8349.04 \\
\hline \multicolumn{11}{|l|}{ Fin } \\
\hline Commercial BG & 3416 & 0.05 & 0.08 & 4.95 & 37.49 & 5088 & 0.11 & 0.35 & 24.50 & 925.41 \\
\hline Savings BG & 24264 & 0.01 & 0.01 & 3.60 & 28.41 & 24392 & 0.01 & 0.01 & 8.79 & 149.53 \\
\hline Cooperative BG & 62873 & 0.01 & 0.02 & 18.58 & 650.47 & 70116 & 0.01 & 0.03 & 19.00 & 600.86 \\
\hline \multicolumn{11}{|l|}{ Ser } \\
\hline Commercial BG & 3416 & 0.45 & 0.19 & 0.46 & 2.94 & 5367 & 0.42 & 0.98 & 64.95 & 4565.16 \\
\hline Savings BG & 23575 & 0.40 & 0.10 & 0.16 & 2.96 & 25031 & 0.31 & 0.12 & 0.61 & 3.54 \\
\hline Cooperative BG & 91368 & 0.30 & 0.13 & 1.01 & 6.33 & 95445 & 0.25 & 0.15 & 1.41 & 6.85 \\
\hline \multicolumn{11}{|l|}{$\mathrm{Mfg}$} \\
\hline Commercial BG & 2375 & 0.20 & 0.11 & 0.68 & 4.56 & 4957 & 0.22 & 0.18 & 1.91 & 10.45 \\
\hline Savings BG & 23322 & 0.20 & 0.09 & 1.12 & 4.87 & 25039 & 0.22 & 0.10 & 0.91 & 4.04 \\
\hline Cooperative BG & 89332 & 0.20 & 0.09 & 0.87 & 4.29 & 95240 & 0.21 & 0.11 & 1.14 & 6.13 \\
\hline
\end{tabular}

-continued on next page- 
-continued from previous page-

Aggregate Lending

\section{L \& C}

Commercial BG

Savings BG

Cooperative BG

1414

12365

18463

$\mathbf{R}$ \& $\mathbf{P}$

Commercial BG

Savings BG

$1509 \quad 0.01$

$\begin{array}{ll}17890 & 0.01\end{array}$

$34205 \quad 0.02$

Cooperative BG

Nmm

Bm

Commercial BG

Savings BG

Cooperative BG

$M$ \& $\mathbf{T}$

Commercial BG

Savings BG

Cooperative BG

$1435 \quad 0.01$

$20366 \quad 0.01$

$49307 \quad 0.01$

\subsection{1}

0.01

0.02

0.01

0.02

0.02

2.65

3.35

4.53

36.19

15.19

30.32

3.96

.

$3.37 \quad 21.60$

13.51

21.13

$\begin{array}{ll}2.90 & 21.17 \\ 3.52 & 23.85 \\ 5.44 & 57.31\end{array}$

$5.44 \quad 57.31$

$\begin{array}{lll}1921 & 0.03 \quad 0.03\end{array}$

$22388 \quad 0.04$

0.04

2.10

9.94

3.63

19.68

$73525 \quad 0.03$

0.04

3.34

22.09

$2060 \quad 0.04 \quad 0.03$

$21872 \quad 0.03$

684590.03

0.02

0.03

1.82

1.62

8.85

6.78

2.119 .60

$E$ \& $O$

Commercial BG

Savings BG

Cooperative BG

$2104 \quad 0.03$

$22082 \quad 0.02$

0.02

0.02

1.47

5.79

$4.71 \quad 45.39$

$3.41 \quad 28.33$

W \& $\mathbf{P}$

Commercial BG

Savings BG

$\begin{array}{lll}2102 & 0.03 & 0.02\end{array}$

$\begin{array}{lll}22842 & 0.04 & 0.03\end{array}$

Cooperative BG

83890

0.05

0.04

1.33

1.92

1.93

6.24

8.60

9.40

Txt

Commercial BG

Savings BG

Cooperative BG

$\begin{array}{lll}1847 & 0.02 & 0.02\end{array}$

$\begin{array}{lll}20626 & 0.01 & 0.02\end{array}$

3.06

3.86

18.45

$59671 \quad 0.02$

0.03

41.06

Fd

$\begin{array}{llllll}\text { Commercial BG } & 2088 & 0.04 & 0.04 & 3.89 & 26.58\end{array}$

Savings BG

$22595 \quad 0.03 \quad 0.02$

1.77

8.21

$3.44 \quad 32.76$

Cooperative BG

$81489 \quad 0.04$

0.04

Short-Term Lending

N Mean Stdev Skew. Kurtosis

32.76

$\begin{array}{lllll}2958 & 0.04 & 0.12 & 8.43 & 92.07 \\ 14576 & 0.01 & 0.02 & 5.59 & 53.80 \\ 26186 & 0.01 & 0.02 & 5.88 & 56.66 \\ & & & & \\ 2374 & 0.02 & 0.07 & 10.30 & 123.91 \\ 19863 & 0.02 & 0.02 & 3.93 & 28.01 \\ 41671 & 0.02 & 0.03 & 5.11 & 61.45\end{array}$

$\begin{array}{lllll}2488 & 0.01 & 0.02 & 4.99 & 44.08 \\ 22571 & 0.01 & 0.02 & 5.54 & 58.93 \\ 57712 & 0.01 & 0.03 & 7.14 & 110.66\end{array}$

$\begin{array}{lllll}3497 & 0.03 & 0.04 & 3.80 & 27.58 \\ 24015 & 0.04 & 0.05 & 3.18 & 16.13 \\ 79953 & 0.03 & 0.04 & 3.96 & 43.46\end{array}$

$\begin{array}{lllll}3824 & 0.05 & 0.09 & 5.82 & 53.64 \\ 23684 & 0.04 & 0.04 & 2.06 & 9.34 \\ 74417 & 0.04 & 0.05 & 3.01 & 18.15\end{array}$

$\begin{array}{lllll}3981 & 0.04 & 0.07 & 9.71 & 144.75 \\ 23743 & 0.03 & 0.03 & 3.69 & 25.55 \\ 79206 & 0.03 & 0.04 & 6.39 & 158.81\end{array}$

$\begin{array}{lllll}3846 & 0.03 & 0.04 & 2.90 & 14.05 \\ 24389 & 0.05 & 0.04 & 2.18 & 10.53 \\ 89981 & 0.06 & 0.05 & 4.60 & 56.21\end{array}$

Notes: Agr = agriculture, Enr = energy and mining, Con = construction, $\mathrm{Trd}=$ wholesale and retail trade, Trt $=$ transport and communication, Fin = finance and insurance, Ser = services, Mfg = manufacturing, $\mathrm{C} \& \mathrm{C}=$ chemicals and coke, $\mathrm{R} \& \mathrm{P}=$ rubber and plastic, $\mathrm{Nmm}=$ non-metallic mineral, $\mathrm{Bm}=\mathrm{metals}, \mathrm{M} \& \mathrm{~T}=$ machinery and transport equipment, $E \& O=$ electrical and optical equipment, $W \& P=$ wood and paper, Txt $=$ textiles, $\mathrm{Fd}=$ food. Lending to industry $\mathrm{i}$ is expressed relative to lending to the grand total of industries. Aggregate bank credit refers to the sum of short-, medium-, and long-term lending. Short-term lending describes lending with maturity of less than one year. Commercial banks include big banks, regional, and private banks. The data are from the quarterly borrower statistics of the Deutsche Bundesbank. 


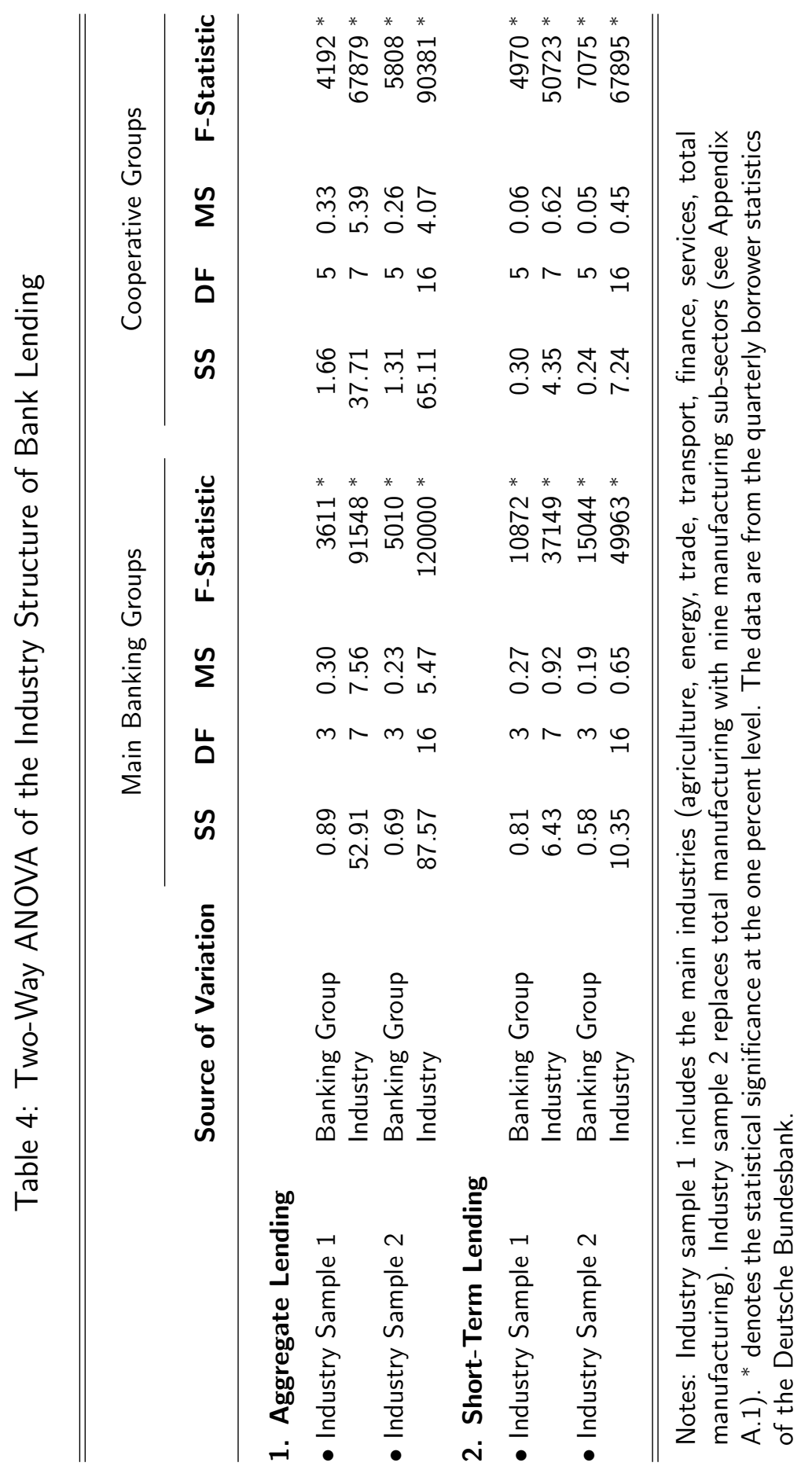




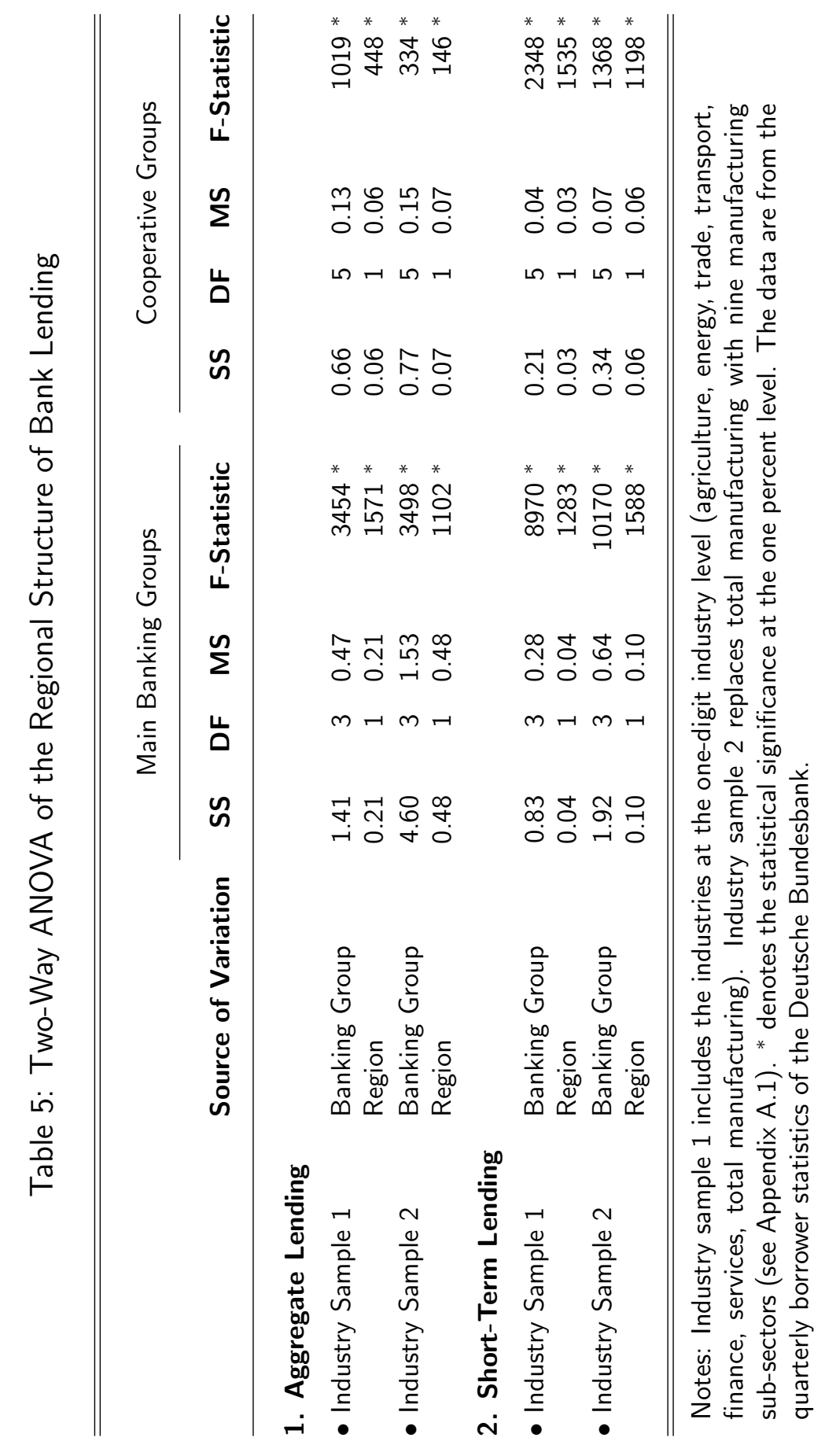


Table 6: Correlation between Industry-Specific Bank Lending and Industry Characteristics Short-Term Bank Lending

\begin{tabular}{|c|c|c|c|c|c|c|c|c|c|c|c|c|}
\hline \multirow[b]{2}{*}{$N / Y$} & \multirow{2}{*}{$\begin{array}{l}\text { Agg. } \\
0.14\end{array}$} & \multirow{2}{*}{$\begin{array}{l}\text { BG } \\
* * *\end{array}$} & \multirow{2}{*}{$\begin{array}{c}\text { Comm } \\
0.03\end{array}$} & \multirow{2}{*}{ BG } & \multicolumn{2}{|c|}{ Savings BG } & \multirow{2}{*}{$\begin{array}{c}\text { Comm. } \\
0.25\end{array}$} & \multirow{2}{*}{$\begin{array}{l}\text { CC } \\
*\end{array}$} & \multicolumn{2}{|c|}{ Rural CC } & \multicolumn{2}{|c|}{ Raiffeisen $B G$} \\
\hline & & & & & 0.23 & * & & & 0.40 & $*$ & 0.55 & * \\
\hline $\mathrm{K} / \mathrm{N}$ & -0.25 & $*$ & -0.17 & $* *$ & -0.34 & * & -0.35 & $*$ & -0.36 & $*$ & -0.34 & $*$ \\
\hline Firm Size & 0.27 & & 0.15 & & 0.38 & & 0.40 & & 0.43 & & 0.47 & \\
\hline Openness & 0.04 & & 0.07 & & 0.004 & & 0.02 & & -0.06 & & -0.15 & $* * *$ \\
\hline Op. Surplus & -0.06 & & -0.08 & $* * *$ & -0.06 & & -0.05 & & 0.03 & & 0.12 & \\
\hline Ind. Size & 0.55 & * & 0.62 & * & 0.44 & * & 0.43 & * & 0.38 & * & 0.30 & $*$ \\
\hline
\end{tabular}

Notes: The pairwise correlation coefficients are constructed for aggregate and short-term lending to 16 industries (agriculture, energy, wholesale and retail trade, transport and communication, finance and insurance, services, and the nine manufacturing sub-sectors; see Appendix A.1). The analysis builds on annual data. The data capture the period 1992-2002 for capital intensity, openness, operating surplus, and industry size and 1999-2000 for firm size. Because of missing values along the time and cross-section dimension, the number of observations tends to be lower than 176 (11 years times 16 industries). The correlation coefficients are computed for the macroeconomic aggregate of short-term bank lending, with short-term credit to industry $\mathrm{i}$ being expressed as share of short-term lending to the grand total of industries. The variables of industry $i$ are measured relative to the corresponding values for the grand total of industries. $*, * *,{ }^{* * *}$ denote the statistical significance at the one, five, and ten percent level, respectively. See section 5 for the data source. 


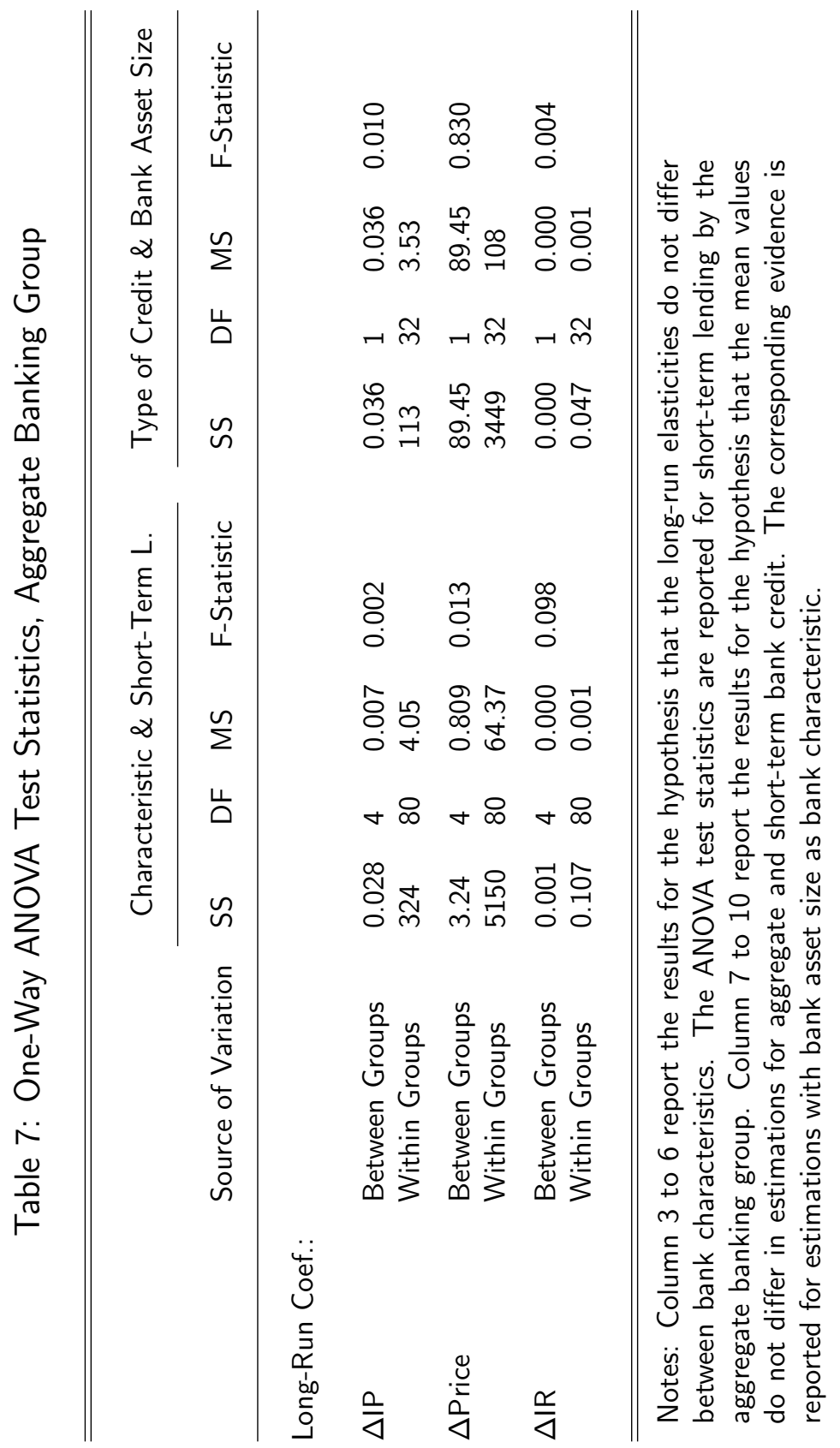


Table 8: Two-Way ANOVA Test Statistics, Short-Term Lending

\begin{tabular}{llllll}
\hline \hline & Source of Variation & SS & DF & MS & F-Statistic \\
\hline \multirow{2}{*}{ Long-Run Coef.: } & & & & & \\
\multirow{2}{*}{$\Delta \mathrm{IP}$} & Banking Group & 7.25 & 3 & 2.42 & 0.77 \\
& Industry & 277 & 14 & 19.81 & $6.32^{*}$ \\
$\Delta$ Price & Banking Group & 7.16 & 3 & 2.39 & 0.18 \\
& Industry & 4345 & 14 & 310 & $23.83^{*}$ \\
$\Delta \mathrm{IR}$ & $\begin{array}{l}\text { Banking Group } \\
\text { Industry }\end{array}$ & 0.006 & 3 & 0.002 & $4.61^{*}$ \\
& 0.098 & 14 & 0.007 & $16.20^{*}$ \\
\hline \hline
\end{tabular}

Notes:The table reports the ANOVA test statistics for short-term lending. The results refer to estimations with bank asset size. ${ }^{*}$ denotes the statistical significance at the one percent level. 


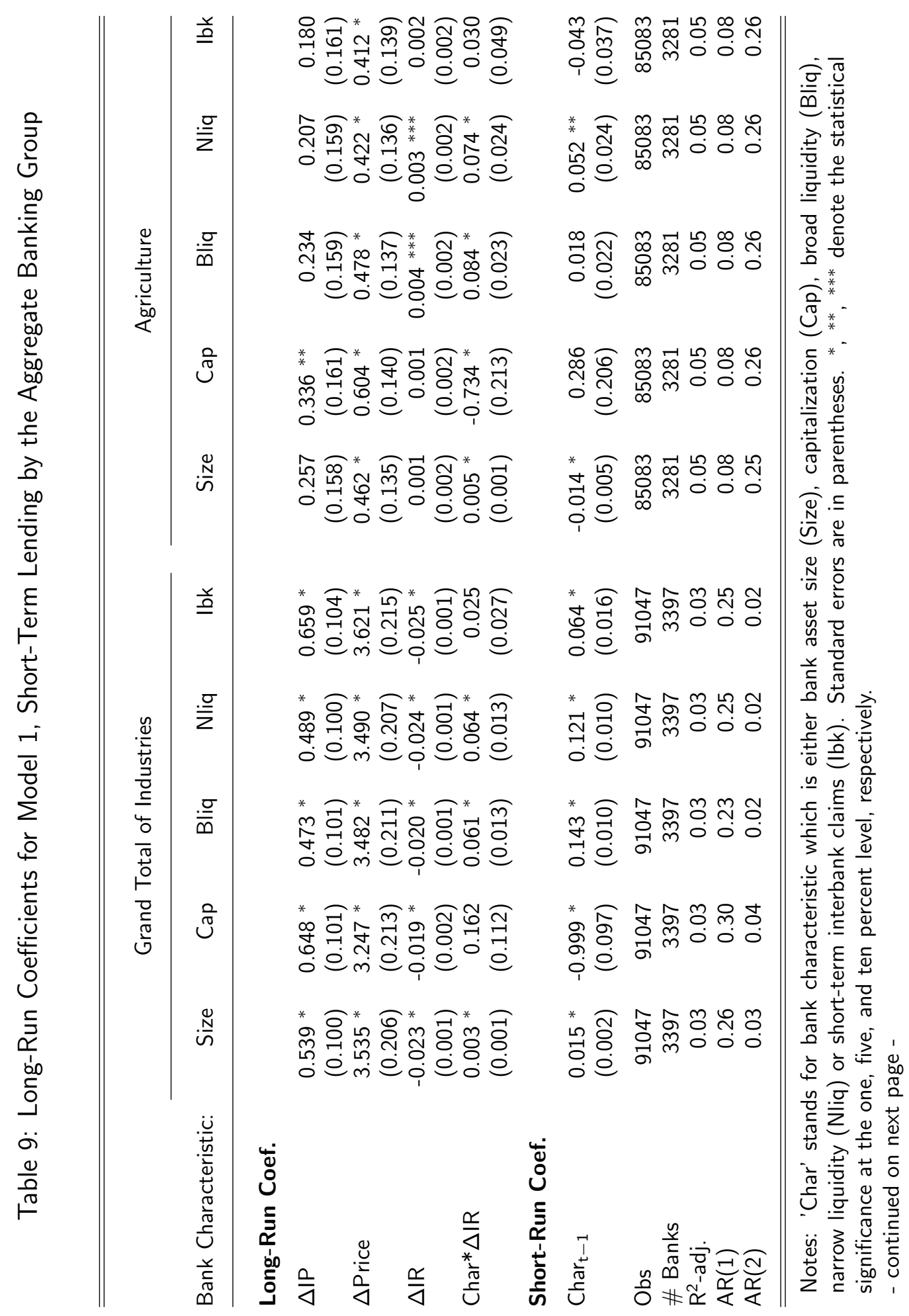




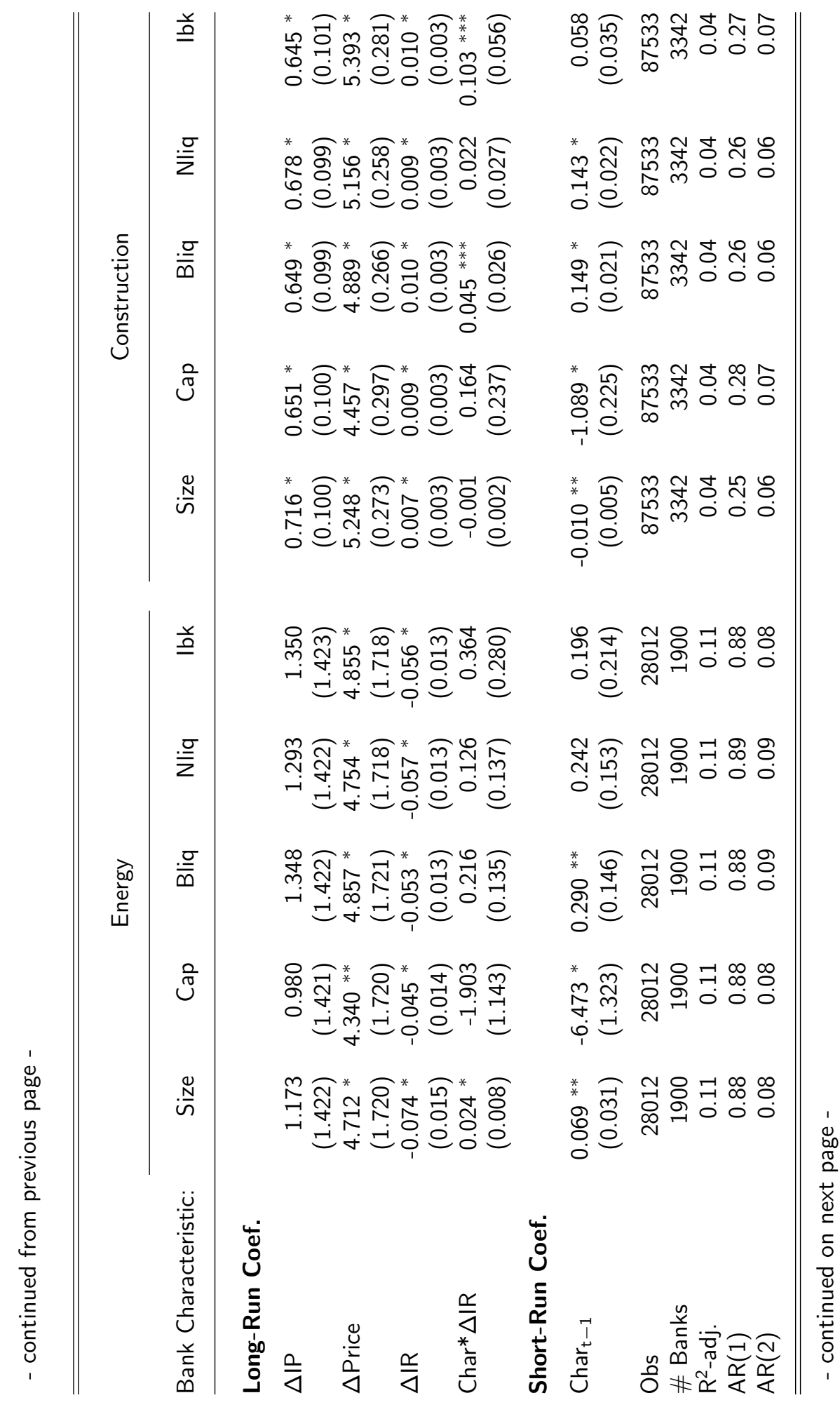




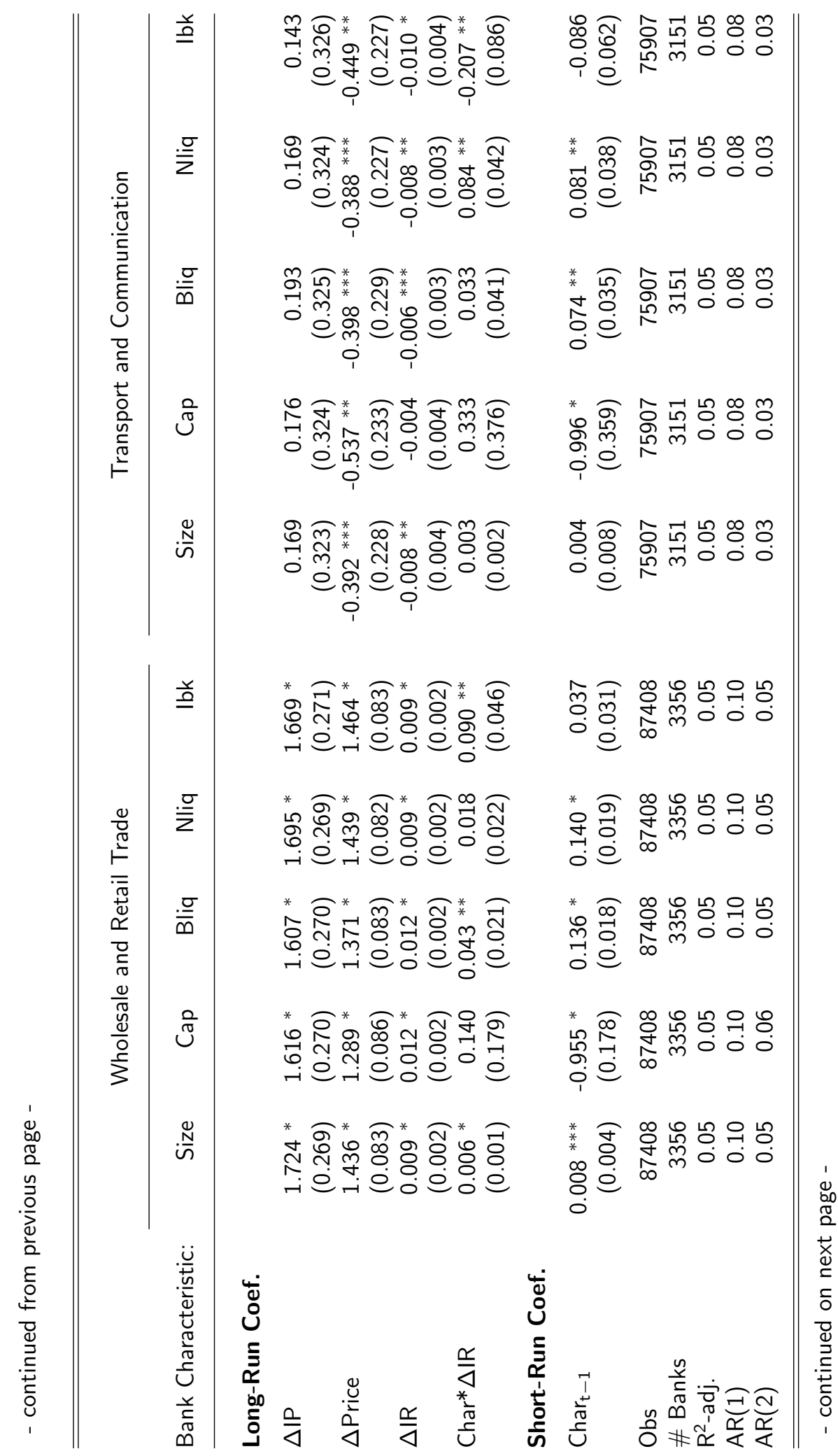




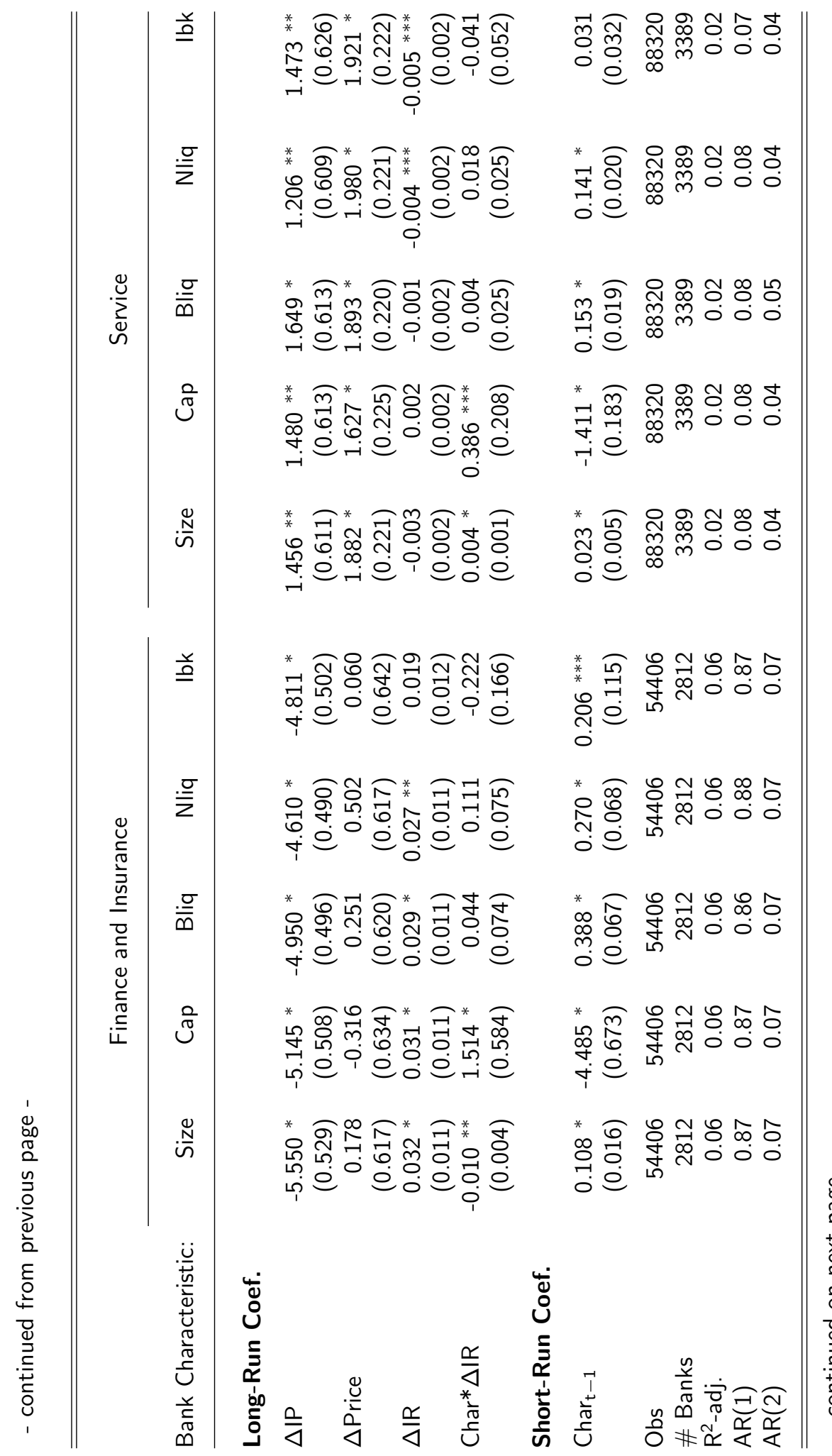




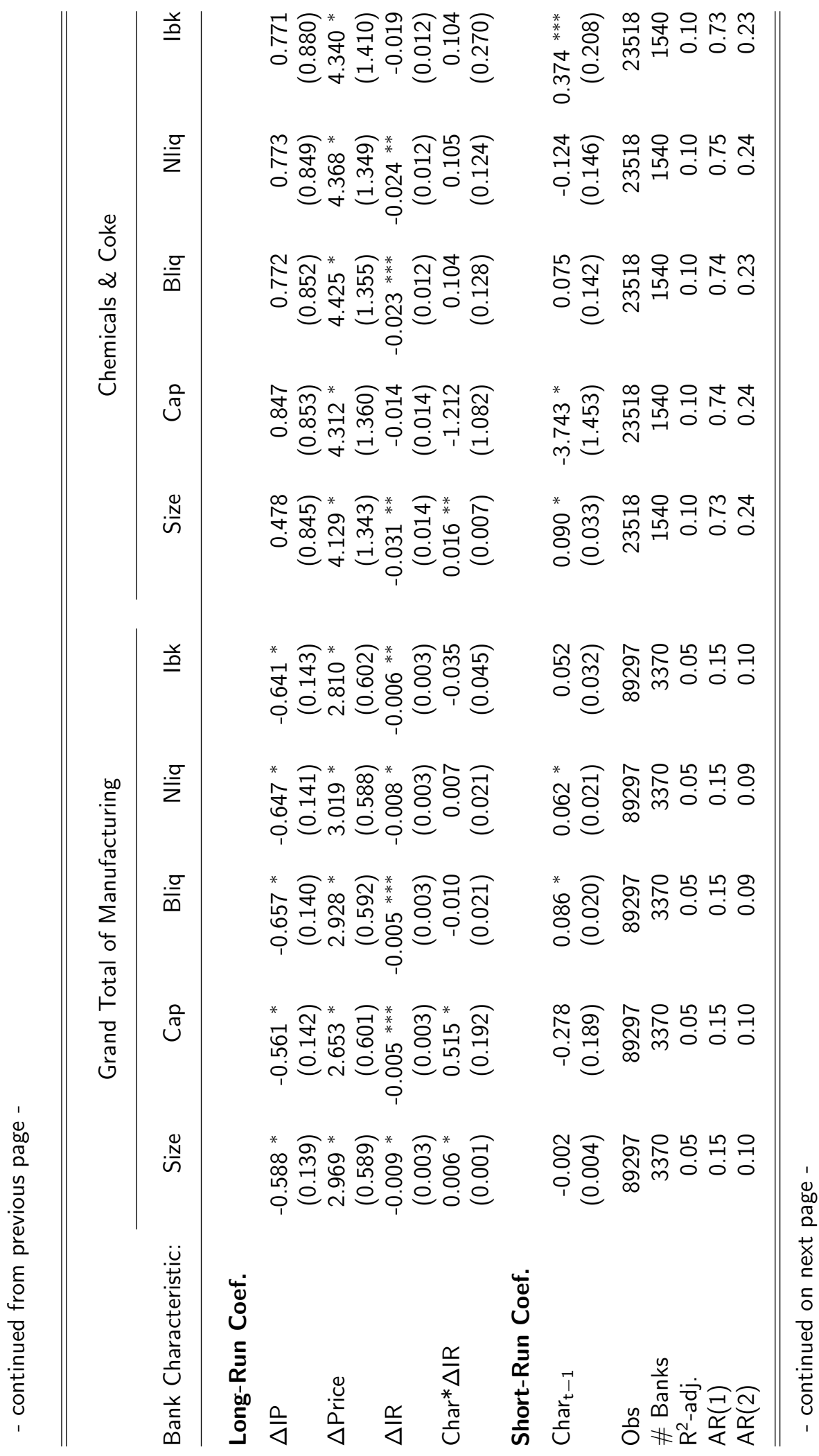




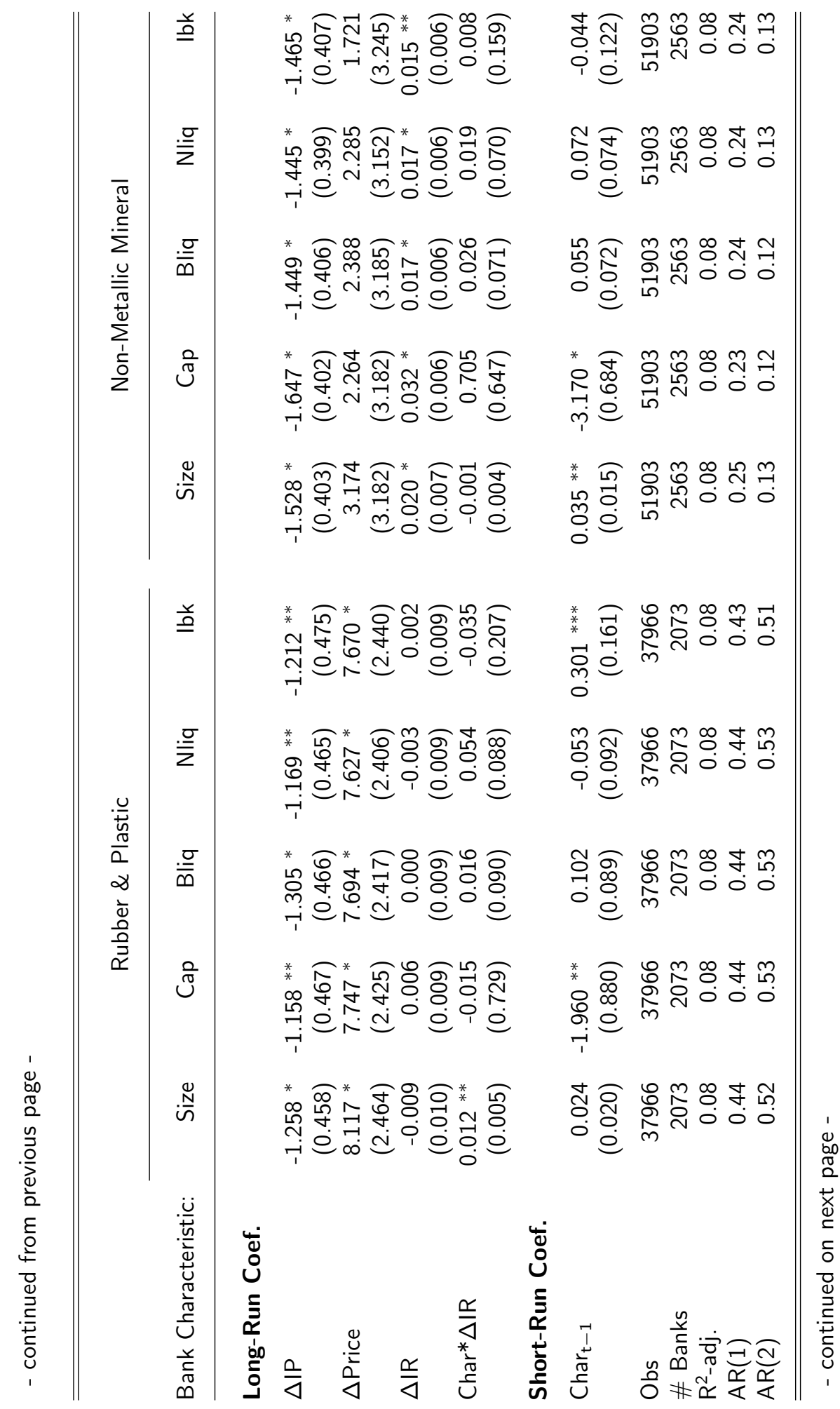




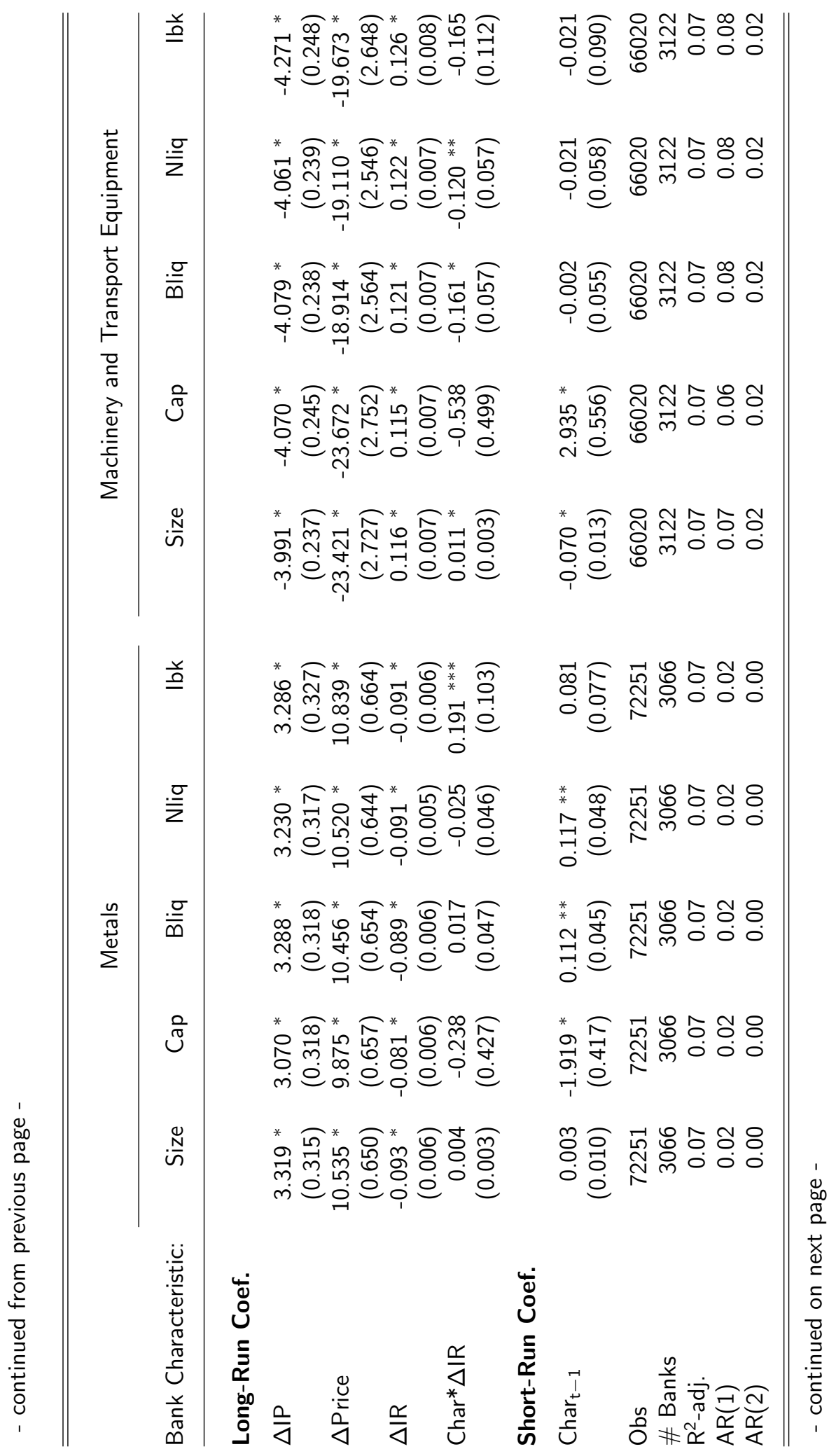




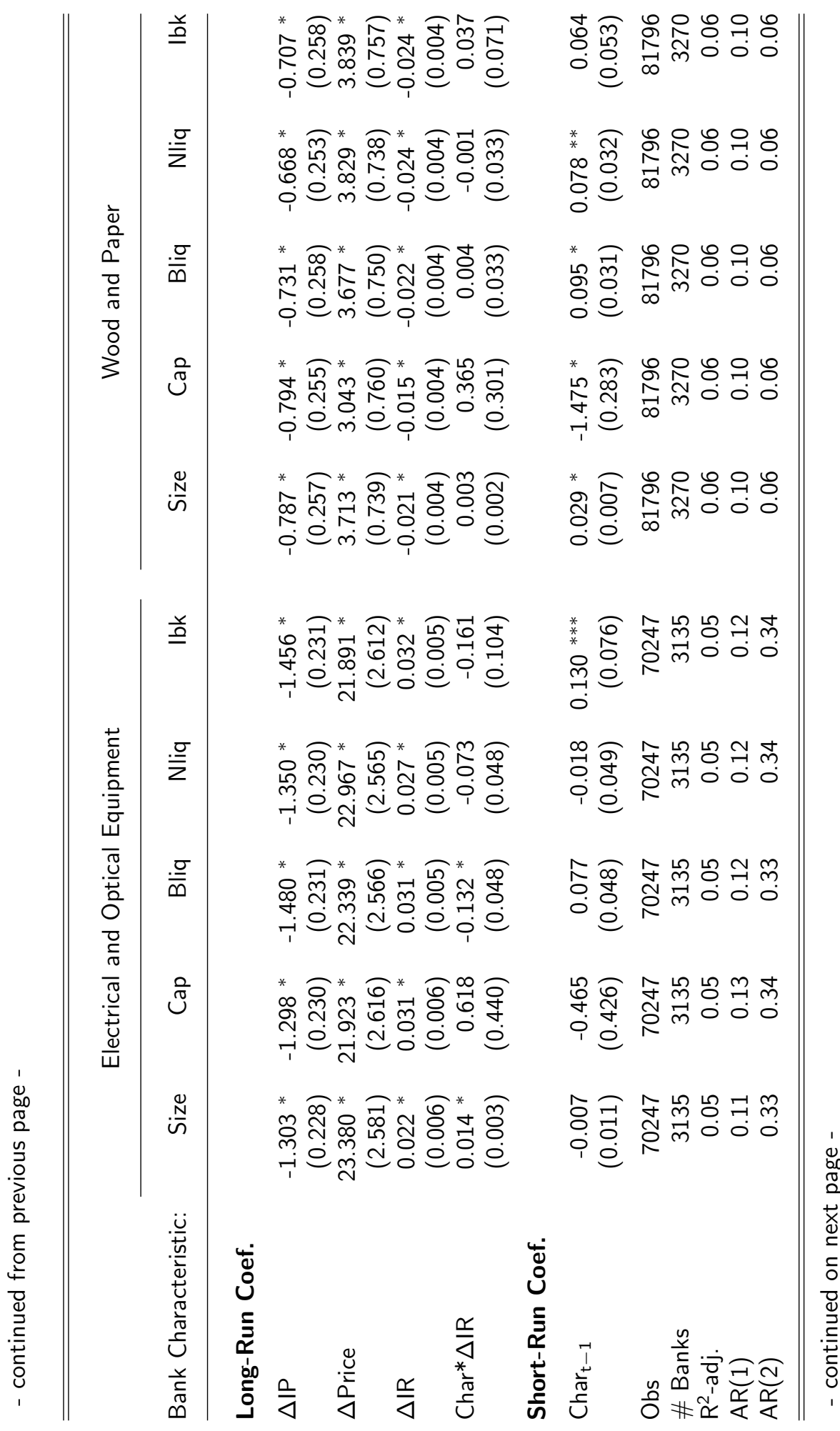




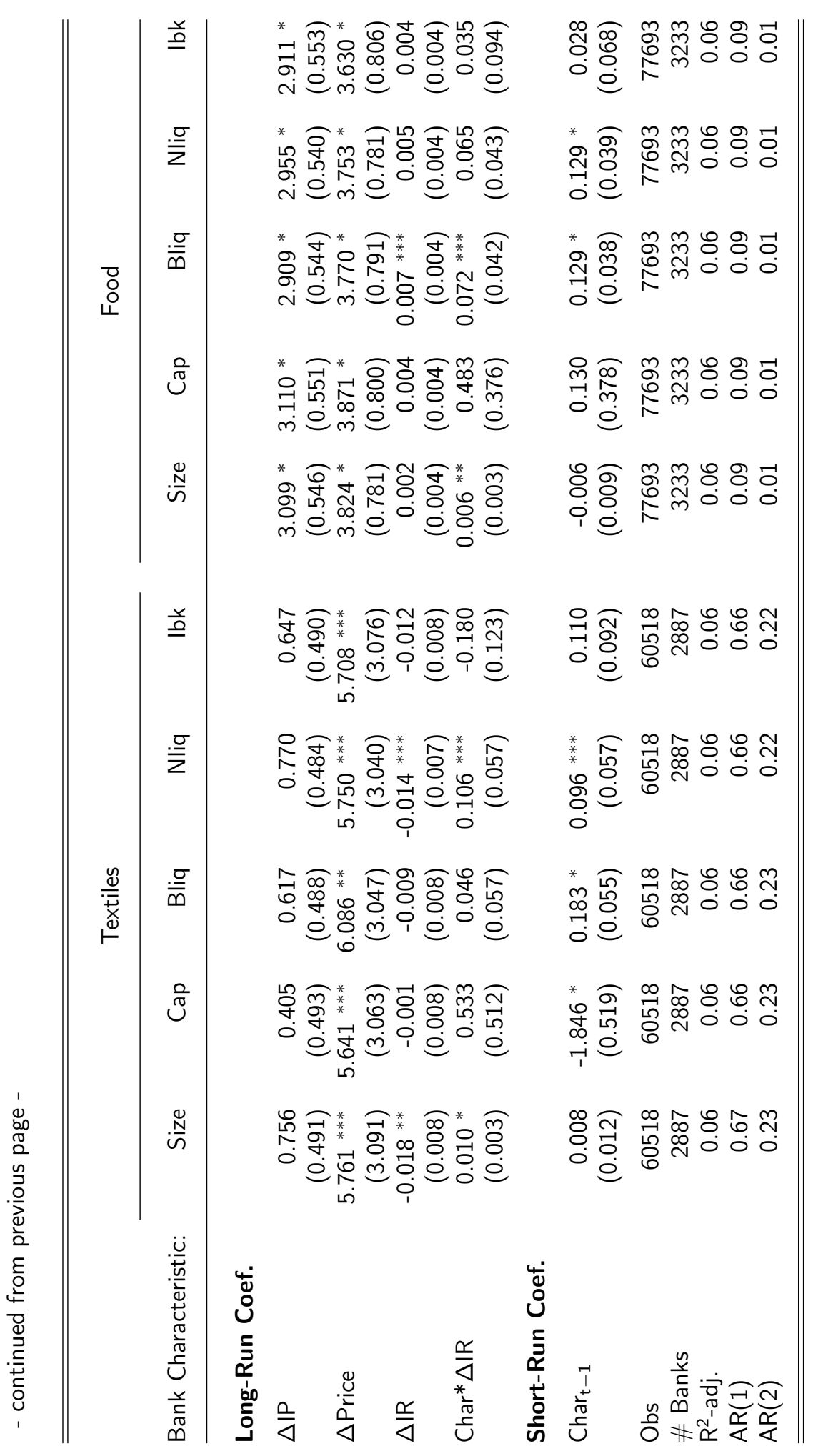

